$1-1-2019$

\title{
Free Speech and the Law of Evidence
}

Dan T. Coenen

University Professor \& Harmon W. Caldwell Chair in Constitutional Law

University of Georgia School of Law

Research Paper Series

Paper No. 2018-21

D bepress

\section{Repository Citation}

Dan T. Coenen, Free Speech and the Law of Evidence, 68 Duke L.J. 639 (2019),

Available at: https://digitalcommons.law.uga.edu/fac_artchop/1165

This Article is brought to you for free and open access by the Faculty Scholarship at Digital Commons @ University of Georgia School of Law. It has been accepted for inclusion in Scholarly Works by an authorized administrator of Digital Commons @ University of Georgia School of Law. Please share how you have benefited from this access For more information, please contact tstriepe@uga.edu. 


\title{
Duke Law Journal
}

\begin{tabular}{lll}
\hline VOLUME 68 & JANUARY 2019 & NUMBER 4 \\
\hline
\end{tabular}

\section{FREE SPEECH AND THE LAW OF EVIDENCE}

\author{
DAN T. COENEN $\dagger$
}

\begin{abstract}
To what extent does the First Amendment limit the ability of prosecutors to offer evidence of a defendant's past protected speech? As it turns out, the Supreme Court has touched on this question in only a handful of rulings, each of which was crafted to target only the distinctive facts of the case at hand. Many lower courts, however, have distilled from these decisions a sweeping, admissibility-favoring constitutional rule. According to that rule, the First Amendment imposes no limit on prosecutorial use of past-speech evidence-no matter how prejudicial-so long as it meets the minimum standard of evidentiary relevance. This approach is misguided. To begin with, it has no support in the Court's past decisions, which in fact favor, rather than disfavor, a meaningful judicial role in evaluating the use of past-speech evidence. Even more important, a hands-off stance clashes with longhonored free-speech-supporting constitutional policies. As a result, this Article calls for judicial recognition of a new set of First Amendment protections that operate whenever challenged past-speech evidence involves expression on a matter of public concern. This build-out of existing doctrine comports with the Court's specialized protection of public-concern speech in a wide variety of settings. It also gains momentum from the Court's jurisprudence regarding constitutional review of generally applicable laws-in this case, the generally applicable law of evidence. On close examination, the operative doctrines in this field-as well as the policy considerations that underlie those doctrines-provide strong support for an approach that imposes
\end{abstract}

Copyright (C) 2019 Dan T. Coenen.

$\dagger$ University Professor and Harmon W. Caldwell Chair in Constitutional Law, University of Georgia School of Law. The author thanks Ronald Carlson, Brannon Denning, Richard Fallon, Walter Hellerstein, Edward Imwinkelried, Henry Monaghan, Mark Tushnet, Sonja West, and Rebecca White for valuable comments on earlier drafts. He also thanks Jared Batte, Grayson Chambers, Ashley Klein, and T.J. Striepe for helpful research and technical assistance. 
both procedural and substantive constraints on the use of publicconcern speech to secure criminal convictions. Such an approach is offered here.

\section{TABLE OF CONTENTS}

Introduction 640

I. The Law of First Amendment Limits on Past-Speech

Evidence 645

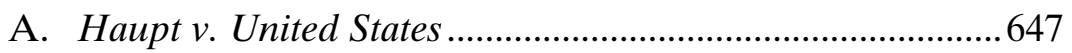

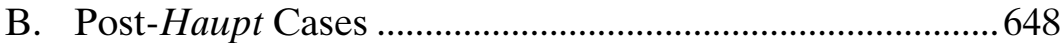

C. The Lower Courts ...................................................................653

II. First Amendment Values and Past-Speech Evidence.....................655

A. Convictions Based on Unfair Prejudice ............................659

B. Convictions Based on "Fair Prejudice" ..............................661

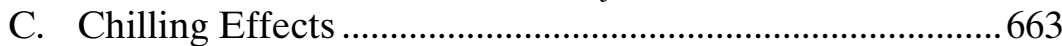

III. Free Speech, Evidence, and Generally Applicable Laws ...........667

A. O'Brien and Generally Applicable Rules of Evidence 671

B. Past-Speech Evidence and Direct-in-Effect Burdens on

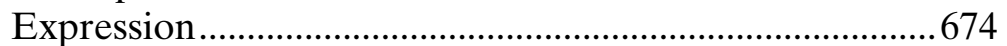

C. Past-Speech Evidence and Sherbert ...................................676

D. Past-Speech Evidence and First Amendment Due Process. 679

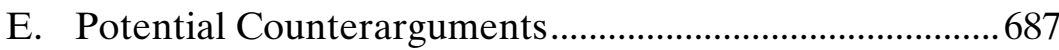

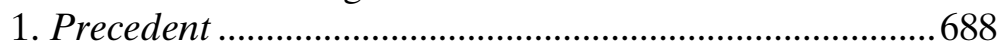

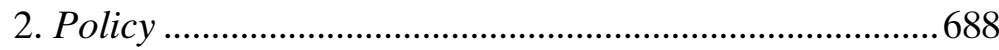

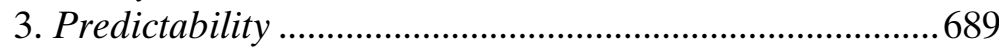

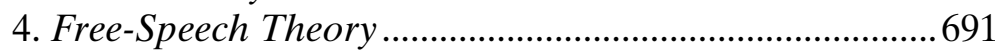

IV. Rules for Evaluating the Use of Past-Speech Evidence .............693

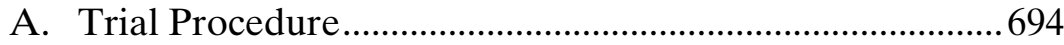

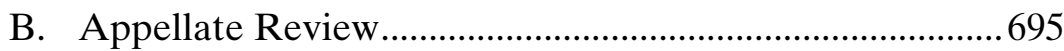

C. The Test of Admissibility ....................................................697

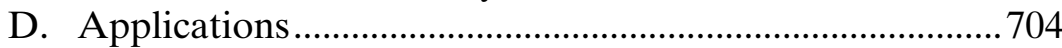

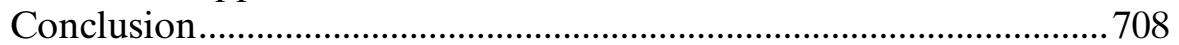

\section{INTRODUCTION}

To what extent does the Free Speech Clause require judges to exclude proof of a criminal defendant's prior statements, otherwise admissible under the rules of general evidence law? Assume, for 
example, that the State seeks to show that the defendant committed murder by bombing a government building. Assume also that the defendant denies any participation in the crime, but an alleged coconspirator says the defendant lit the fuse. To help prove that he did so, can the prosecutor offer testimony that the defendant once declared himself to be a member of al-Qaeda? That, even if the defendant never joined al-Qaeda, he had spoken about the justifiability of Jihad? That several weeks earlier he declared in a speech that current national policies warranted violent revolution? That hours before the bombing he told a friend that the government had become intolerably misguided? Each of these items of evidence would tend to show that the defendant had a motive to engage in the bombing. As a result, they would appear to be relevant and thus admissible under the general law of evidence - or at least some judges might so rule.

The admission of any of these statements, however, would raise significant tensions with the First Amendment. Under well-settled Free Speech Clause law, after all, the government could not send the defendant to jail simply because he made these utterances or because of the views or associations these utterances reflect. Yet, revealing any one of these statements to the jury might have the same practical effect by decisively leading it to convict the defendant of the charged crime. Evidence of this kind also invites a finding of guilt based on justifications derived directly from the protected content of the defendant's past speech-reasons such as a perceived lack of patriotism, political radicalism, or potential for "off the wall" behavior. The question thus arises whether a prosecutor's use of this type of evidence-what is called here "past-speech evidence"-offends the First Amendment.

The practical problems posed by the use of past-speech evidence are far-reaching. Indeed, prosecutors offer proof of defendants' past statements on a daily basis in their efforts to secure convictions. And these prior statements-commonly called "admissions"-routinely come into evidence, even though they constitute instances of speech. ${ }^{1}$ More subtly, but no less importantly, the analytical issues raised by the use of past-speech evidence ripple across major domains of First Amendment law. Most notably, these cases simultaneously bring into play Supreme Court jurisprudence regarding the special protections applicable to speech on matters of public concern; the extent to which

1. See FED. R. EvID. 801(d)(2) (utilizing the more recent, and more accurate, terminology of "[a]n [o]pposing [p]arty's [s]tatement"). 
the Free Speech Clause can support as-applied challenges to generally applicable laws; and the reach of constitutional limits that stem from so-called "First Amendment due process." It follows that the matters considered here both implicate and help illuminate foundational features of free-expression-law theory, doctrine, and practice.

Indeed, issues regarding the Government's introduction of pastspeech evidence have surfaced in some of the highest-profile cases in American history, including the 1921 trial of Sacco and Vanzetti, the 1951 espionage trial of Julius and Ethel Rosenberg, and the 1969 trial of the Chicago Eight. ${ }^{2}$ Perhaps for this reason, analysts have suggested that controversies over past-speech evidence most often arise in times of "political tension." Political tension, however, is a recurring component of the American experience, fueled by such matters as antiwar protests, labor-related and other counterculture movements, conflicts rooted in religious dissent, and the ever-churning challenges stirred by our nation's racial divisions. In recent years, for example, courts have faced challenges to prosecutorial use, as evidence, of rap lyrics authored by criminal defendants that are said to celebrate violence or drug use. ${ }^{4}$

Given these conditions, one might expect that courts and commentators would have worked through how evidence law and the Free Speech Clause should and do fit together. As it turns out, however, only one major scholarly article, written by Professor Peter E. Quint, grapples with past-speech-evidence problems, and that piece is now more than four decades old. ${ }^{5}$ In addition, prior judicial treatments of these problems are marked by inconsistency and a lack of analytical depth. ${ }^{6}$ One consequence of all of this is that lawyers may

2. See Peter E. Quint, Toward First Amendment Limitations on the Introduction of Evidence: The Problem of United States v. Rosenberg, 86 YALE L.J. 1622, 1623 n.4, 1624, 1645 (1977).

3. Id. at 1678 .

4. See, e.g., Andrea L. Dennis, Poetic (In)justice? Rap Music Lyrics as Art, Life, and Criminal Evidence, 31 COLUM. J.L. \& ARTS 1, 2 (2007); Sean-Patrick Wilson, Rap Sheets: The Constitutional and Societal Complications Arising from the Use of Rap Lyrics as Evidence at Criminal Trials, 12 UCLA ENT. L. REV. 345, 359-64 (2005).

5. Quint, supra note 2. Another helpful treatment is Robert P. Faulkner, Evidence of First Amendment Activity at Trial: The Articulation of a Higher Evidentiary Standard, 42 UCLA L. REV. 1 (1994), though it largely builds on Professor Quint's earlier work. See also Helen A. Anderson, The Freedom to Speak and the Freedom to Listen: The Admissibility of the Criminal Defendant's Taste in Entertainment, 83 OR. L. REV. 899, 902 (2004) (noting that "a criminal defendant's viewing, listening, or reading habits may be used as evidence against that defendant, and that the constitutional implications of such evidence are rarely discussed").

6. See Amy Pomerantz Nickerson, Coercive Discovery and the First Amendment: Towards 
well miss chances to register objections to the introduction of potentially excludable past-speech proof or to frame objections in proper terms. $^{7}$

These dynamics stem in part from another curiosity: the Supreme Court has squarely confronted the sort of question considered here in only one prior case, Haupt $v$. United States. ${ }^{8}$ In the seven decades since Haupt, however, free-speech doctrine has undergone a process of allbut-revolutionary change. This process has engaged the Court in building out a host of new speech-protective doctrines-especially for speech on "matters of public concern" - that push in favor of placing constitutional limits on the use of past-speech evidence. On the other hand, a restraintist approach might - at least at first blush - seem to find support in modern precedents that reflect judicial hesitance to vindicate as-applied challenges to so-called "generally applicable laws." ${ }^{10}$ There is, however, a large problem with urging that the generally applicable character of evidence law precludes as-applied challenges to the introduction of past-speech evidence. The problem is that key decisions of the Court-such as Sherbert v. Verner, ${ }^{11}$ United States v. O'Brien, ${ }^{12}$ Holder v. Humanitarian Law Project, ${ }^{13}$ and a host of First Amendment due process rulings ${ }^{14}$-support the making of context-specific constitutional challenges to generally applicable laws. Moreover, the expression-protective features of these authorities find their driving force in policy reasons that carry over in powerful ways to past-speech-evidence cases. In sum, both the key authorities and their underlying logic suggest that courts are constitutionally required to thoughtfully assess the admissibility of past-speech evidence,

a Heightened Discoverability Standard, 57 UCLA L. REV. 841, 845 (2010) (noting “doctrinal inconsistencies and confusion").

7. See United States v. Ring, 706 F.3d 460, 473 (D.C. Cir. 2013) (noting counsel's failure in lodging an objection "to specify exactly what role constitutional considerations should play"); Anderson, supra note 5, at 901 (noting that missed opportunities sometimes arise because "the law in this area is underdeveloped"); see also United States v. Cabrera-Beltran, 660 F.3d 742, 751 (4th Cir. 2011) (requiring that evidentiary objections on constitutional grounds - there, pursuant to the Confrontation Clause-be specifically so made).

8. Haupt v. United States, 330 U.S. 631 (1947).

9. Snyder v. Phelps, 562 U.S. 443, 453, 458 (2011).

10. See infra notes $107-12$ and accompanying text.

11. Sherbert v. Verner, 374 U.S. 398 (1963).

12. United States v. O'Brien, 391 U.S. 367 (1968).

13. Holder v. Humanitarian Law Project, 561 U.S. 1 (2010).

14. See infra Part III.D. 
regardless of its relevance, pursuant to a speech-sensitive balancing analysis when prosecutors seek to use that evidence at trial.

This Article develops these ideas in four parts. Part I canvasses the Court's rulings on past-speech evidence, demonstrating that none of those rulings, apart from the well-aged decision in Haupt, deals squarely with the intersection of the rules of evidence and the Free Speech Clause. Part I also explains that despite the contrary views of many lower courts, no prior Supreme Court ruling - including Dawson v. Delaware ${ }^{15}$-supports the admission of all relevant past-speech evidence regardless of First Amendment considerations. ${ }^{16}$ Part II goes on to show that the Court's post-Haupt rulings on expression related to matters of public concern in fact support placing meaningful constitutional limits on the use of past-speech evidence. Part III then turns to the Court's jurisprudence of generally applicable rules and demonstrates why that body of law likewise cuts in favor of, rather than against, the recognition of such limits.

Finally, Part IV considers what those limits should be. Drawing on precedents crafted in analogous contexts, it posits (1) that trial judges, after hearing arguments away from the jury, should have to issue reasoned rulings whenever defendants object to prosecutorial use of public-concern-related past-speech proof, and (2) that appellate courts should subject adverse rulings on such objections to a form of review much more exacting than the abuse-of-discretion standard ordinarily applied in this set of cases. Part IV goes on to reject a variety of possible substantive legal tests for assessing whether past-speech evidence is rightly subject to exclusion. The best approach, according to the synthesis presented in Part IV, is one that requires courts to weigh whether the government's interest in using any item of such evidence outweighs all the costs that introducing it would place on First Amendment concerns - with an emphasis on the point that those concerns reach much further than others have recognized in the past.

Embracing this set of rules would, as it ought to, constitutionalize evidence law with regard to prosecutorial use of past-speech evidence. It is understandable that many trial lawyers, trial courts, and evidence law scholars tend to view these cases through the lens of Federal Rule of Evidence 403. This rule, after all, permits judges to exclude evidence that present risks of "unfair prejudice." ${ }^{17}$ The doctrine for policing

\footnotetext{
15. Dawson v. Delaware, 503 U.S. 159 (1992).

16. See infra notes 34-35, 41-47, 53-66 and accompanying text.

17. FED. R. EVID. 403.
} 
past-speech evidence proposed in this Article, however, reaches well beyond the minimal limits imposed by Rule 403 and the jurisprudence that has crystallized around it. And that is as it should be. Precisely because past-speech evidence raises specialized First Amendment concerns, a specialized set of First Amendment restrictions should control its use.

There is no pretense here that applying these restrictions will always be easy. Even more emphatically, there is no suggestion that defendants should routinely, or even commonly, succeed when they raise Free Speech Clause objections to the use of past-speech proof. If core First Amendment values are to receive their fair due, however, courts should afford such objections more than an unthinking, waveof-the-hand dismissal when public-concern speech is in the picture. This Article shows how courts can and should deal more thoughtfully with the serious constitutional problems posed by prosecutorial use of past-speech evidence.

\section{THE LAW OF FIRST AMENDMENT LIMITS ON PAST-SPEECH EVIDENCE}

Many trials involve the use of past speech as evidence. Most cases, however, do not concern the sort of constitutional issues that are the subject of this Article. For example, confessions made to police officers come in the form of words. But no one would suggest that the Free Speech Clause bars the admission of those confessions at trial. Other forms of speech-based evidence also fall beyond the scope of this Article because they do not, even remotely, involve expression on matters of public concern. Illustrative are intercepted crime-planning communications ("Let's meet in an hour to get ready for the bank robbery.") and pre-crime inculpatory statements ("Tomorrow, I'm going to kill Mortimer!").

Also outside the scope of this Article are three types of cases that do involve public-concern-speech evidence. First, some cases involve prosecutorial use of past public-concern-related utterances made not by the criminal defendant, but by a third-party witness. In these cases, any burden placed on the speaker typically is limited. Defense witnesses, for example, might experience discomfort when prosecutors impeach them based on prior inconsistent statements they made on public issues. But any such burden on speech is far removed from a criminal conviction of a defendant supported by that defendant's own past pronouncements. 
Second, in some cases, litigants offer evidence of past speech by a government official in seeking civil relief not against that official, but (at least in practical effect) against the government itself. ${ }^{18}$ Courts, for example, have considered evidence of President Trump's pre-election statements about Muslims in lawsuits challenging the so-called "travel ban."19 But an effort to secure injunctive relief from a government entity-which did not itself previously utter any words-is very different from a prosecutor's use of an individual's past speech as evidence of that very individual's commission of a crime. Cases of that sort, accordingly, are not considered here.

Finally, past-speech evidence sometimes is offered against individual defendants in civil proceedings, including when plaintiffs seek monetary relief. It may be that the arguments made here with regard to criminal prosecutions should carry over to such cases,${ }^{20}$ especially because the Court often equates civil remedies and criminal sanctions when applying First Amendment limits. ${ }^{21}$ Perhaps, however, close analysis will reveal reasons to treat civil and criminal cases differently in this context. ${ }^{22}$ This Article thus leaves it to others to explore how the First Amendment bears on the use of evidence in civil trials, administrative hearings, and other noncriminal decision-making processes.

18. Among these cases are those in which injunctive relief is nominally, but not functionally, sought against a named government official under the doctrine of Ex parte Young, 209 U.S. 123 (1908).

19. See, e.g., Int'l Refugee Assistance Project v. Trump, 857 F.3d 554, 591 (4th Cir.) (considering "numerous campaign statements expressing animus towards the Islamic faith"), vacated and remanded by 138 S. Ct. 353 (2017). In Trump v. Hawaii, 138 S. Ct. 2392 (2018), the Supreme Court upheld the travel ban but emphasized the special circumstances of the case in doing so. See id. at 2418-20. Of particular importance to the Court's endorsement of a very "narrow standard of review" was the origin of the travel restriction in both foreign-affairs-related immigration policy and "national security" concerns. Id. at 2419 (citation omitted). Even in this context, however, the Court did not disclaim all authority to consider the "plaintiff's extrinsic evidence." Id. at 2420. For a detailed discussion of the how courts should approach campaignspeech evidence as a general matter when government motives are at issue, see Michael B. Coenen, Campaign Communications and the Problem of Government Motive, 18 U. PA. J. CONST. L. (forthcoming 2018).

20. See Faulkner, supra note 5, at 15-16.

21. See, e.g., Garrison v. Louisiana, 379 U.S. 64, 67 (1964); see also Michael B. Coenen, Of Speech and Sanctions: Toward a Penalty-Sensitive Approach to the First Amendment, 112 COLUM. L. REV. 991, 993-94 (2012).

22. See Dan T. Coenen, Freedom of Speech and the Criminal Law, 97 B.U. L. REV. 1533, 1563-77 (2017) (developing this idea by highlighting that different forms of sanctions, civil or criminal in character, can have a key impact in the application of Free Speech Clause protections). See generally Coenen, supra note 21 (developing this differential-sanction concept in detail). 
In sum, this Article considers only prosecutorial use of publicconcern-related speech made by defendant-declarants. The Supreme Court has touched on this subject in several rulings. ${ }^{23}$ In only three cases, however, has it dealt specifically with objections to evidentiary use of such speech. And in only one case-Haupt-did the Court confront a constitutional challenge to the use of past-speech evidence that was deemed relevant to a disputed factual issue.

\section{A. Haupt v. United States}

The prosecution of Hans Max Haupt, a German-born naturalized American citizen, arose out of the surreptitious entry of a group of Nazi saboteurs, including Haupt's son, into the United States during World War II. ${ }^{24}$ The indictment charged Haupt with conspiring to commit treason after his son arrived in the country. ${ }^{25}$ The overt acts said to support this allegation included Haupt's purchase of a car for his son's use, his helping his son get a job in a munitions plant, and his allowing his son to live in the family home. ${ }^{26}$ At trial, Haupt argued that these actions were not motivated by a desire to aid the enemy, as the charged crime required, but instead by the natural parental impulse to help one's child. ${ }^{27}$ In response, the Government offered proof, admitted by the trial judge, of statements "showing sympathy with Germany and with Hitler." 28 In particular, the prosecution proved that Haupt had stated "that after the war he intended to return to Germany, that the United States was going to be defeated, that he would never permit his boy to join the American Army, [and] that he would kill his son before he would send him to fight Germany." 29

On appeal, Haupt argued that the trial court erred in permitting the Government to use these statements as evidence against him, ${ }^{30}$ but

23. See infra notes 70, 114-21 and accompanying text (discussing Wisconsin v. Mitchell, 508 U.S. 476 (1993)) and note 314 (discussing Price Waterhouse v. Hopkins, 490 U.S. 228 (1989)); see also Barclay v. Florida, 463 U.S. 939, 948-49 (1983) (deeming the defendant's proven "desire to start a race war" relevant to establishing the aggravating factor of creating a "great risk of death to many persons," but focusing on the defendant's assertion, unrelated to evidence law, that "racial motive" had improperly operated as a "non-statutory aggravating circumstance").

24. Haupt v. United States, 330 U.S. 631, 633 (1947).

25. Id. at 633-34.

26. Id. at 634 .

27. Id. at 641 .

28. Id. at 642 .

29. Id.

30. Id. 
Justice Jackson rejected this argument in an opinion for the Court. ${ }^{31}$ Providing only a single-paragraph treatment of the issue, Jackson reasoned that "these statements were explicit and clearly were admissible on the question of intent and adherence to the enemy" because they showed "hostility to the United States." 32 At the same time, he observed that "[s]uch testimony is to be scrutinized with care to be certain the statements are not expressions of mere lawful and permissible difference of opinion with our own government or quite proper appreciation of the land of birth." ${ }^{33}$ Haupt thus leaves behind tricky questions. It is no small problem, after all, to separate statements that reflect "hostility to the United States" from statements that reflect a mere "difference of opinion with our own government." ${ }^{34}$ In addition, the Court's terse analysis cannot fairly be viewed as doing more than resolving the discrete evidentiary dispute raised by the facts of the case. Haupt does not hold, or even suggest, that the First Amendment never blocks prosecutorial use of otherwise relevant evidence, particularly under modern-day principles of free-expression law. Indeed, Haupt signals-albeit while offering no particularized guidance on this point-that the introduction of past-speech evidence "is to be scrutinized with care. ${ }^{n 5}$

\section{B. Post-Haupt Cases}

Several post-Haupt cases touch on the subject of prosecutorial use of past-speech evidence-most notably, United States v. Abe ${ }^{36}$ and Dawson v. Delaware. ${ }^{37}$ But these rulings, like Haupt, fall far short of negating all Free Speech Clause limits on the Government's use of relevant past-speech evidence in criminal prosecutions. Indeed, close examination shows that they do not signal in any way the propriety of

\section{Id.}

32. Id. As it turns out, in considering this issue, the majority in Haupt made no express reference to the First Amendment. For this reason, some observers might try to claim that the case does not involve an application of constitutional principles, as opposed to principles of general evidence law. At the very least, however, the Court in its later work has relied on Haupt in laying down governing constitutional principles. See Wisconsin v. Mitchell, 508 U.S. 476, 476, 489-90 (1993). As a result, the analysis set forth here proceeds on the assumption that, under authority laid down by the Supreme Court, the admission of the prior-speech evidence in Haupt comported with First Amendment requirements.

33. Haupt, 330 U.S. at 642.

34. Id.

35. Id.

36. United States v. Abel, 469 U.S. 45, 46-48 (1984).

37. Dawson v. Delaware, 503 U.S. 159, 160-64 (1992). 
limiting free-expression rights in this set of cases. Particularly unenlightening on this score is the Court's 1984 ruling in Abel. There, in a prosecution for bank robbery, the defendant offered the testimony of a witness, Robert Mills, indicating that a third person had tried to frame the defendant as a means of escaping punishment for the crime. ${ }^{38}$ In response, the Government submitted proof of the membership of both the defendant and the defense witness Mills in the Aryan Brotherhood, as well as testimony that Brotherhood members were sworn to lie on each other's behalf..$^{39}$ The Court upheld the trial judge's admission of this evidence, deeming it probative of the witness's bias and resulting lack of credibility. ${ }^{40}$

For two separate reasons, $\mathrm{Abel}$ is uninformative with regard to the matter considered in this Article-that is, the scope of First Amendment limits on evidentiary use of a criminal defendant's prior statements. First, that case did not involve a constitutional question at all. Rather, the defendant himself proceeded from the assumption "that the question is governed by the Federal Rules of Evidence" in particular, Rule 403, which provides for the exclusion of relevant evidence "if its probative value is substantially outweighed by a danger of ... unfair prejudice, confusing the issues, [or] misleading the jury." ${ }^{42}$ In turn, the Court found no reversible error because the trial court had not "abused its discretion under Federal Rule of Evidence 403," particularly because the "district court is accorded a wide discretion in determining the admissibility of evidence under the Federal Rules." ${ }^{44}$ Second, the Court specifically distinguished the ordinary case involving past-speech evidence. It emphasized that the "highly probative" 45 proof presented in Abel "was not offered to convict [the defendant Abel] of a crime, but to impeach Mills' testimony." 46 As a result, Abel offers no guidance in assessing objections-especially First Amendment objections-to past statements made by defendants

\footnotetext{
38. Abel, 469 U.S. at 47.

39. Id.

40. Id.

41. Id. at 49 .

42. FED. R. EVID. 403.

43. Abel, 469 U.S. at 53.

44. Id.

45. $I d$. at 55 .

46. Id. at 53 .
} 
themselves and offered by the prosecution as substantive evidence of guilt. ${ }^{47}$

The Court's latest encounter with a free-speech-based evidentiary objection came in Dawson v. Delaware. That case concerned a sentencing hearing that followed a jury's finding that the defendant, a white man, had committed the murder of a white victim during a burglary in the wake of a prison escape. ${ }^{48}$ At the sentencing hearing, the trial judge admitted evidence that the defendant was a member of an Aryan Brotherhood gang at the Delaware State Penitentiary as well as a stipulation that read in its entirety: "The Aryan Brotherhood refers to a white racist prison gang that began in the 1960's in California in response to other gangs of racial minorities. Separate gangs calling themselves the Aryan Brotherhood now exist in many state prisons including Delaware." ${ }^{49}$ On these facts, the Delaware Supreme Court upheld the jury's imposition of the death sentence. ${ }^{50}$ It acknowledged that this evidence did not bear on the three death-sentence-supporting aggravating circumstances on which the prosecution had reliednamely, that the murder was committed (1) by an escaped prisoner, (2) during a burglary, and (3) for monetary gain..$^{51}$ Even so, the state court concluded that the evidence tended to establish the defendant's bad character, thus appropriately counterbalancing the defendant's mitigating evidence of good character as shown by his past acts of kindness to family members and voluntary participation in drug and alcohol rehabilitation programs. ${ }^{52}$

Writing for eight members of the Court, Chief Justice Rehnquist overturned the state court ruling on the ground that the challenged evidence had "no bearing" on the issues in the case..$^{53} \mathrm{He}$ emphasized at the outset "that the Constitution does not erect a per se barrier to the admission of evidence concerning one's beliefs and associations at sentencing simply because those beliefs and associations are protected by the First Amendment." ${ }^{54}$ In this case, however, the challenged evidence lacked significance because the two-sentence stipulation

47. Accord Faulkner, supra note 5, at 36 n.221 (noting that Abel does not address a First Amendment challenge).

48. Dawson v. Delaware, 503 U.S. 159, 160-61 (1992).

49. Id. at 162 (citation omitted).

50. Id. at 163 .

51. Id. at $162-63$.

52. Id.

53. Id. at 168 .

54. Id. at 165 . 
about the Aryan Brotherhood provided only minimal information, ${ }^{55}$ and because the racist nature of the Brotherhood had no meaningful connection to the white-on-white murder. ${ }^{56}$ The Chief Justice noted that "we would have a much different case" if the State had proved "that the Aryan Brotherhood is a white racist prison gang that is associated with drugs and violent escape attempts at prisons, and that advocates the murder of fellow inmates." ${ }^{57}$ On the actual facts, however:

Whatever label is given to the evidence presented, ... we conclude that Dawson's First Amendment rights were violated by the admission of the Aryan Brotherhood evidence . . . , because the evidence proved nothing more than Dawson's abstract beliefs. ... [O]n the present record one is left with the feeling that the Aryan Brotherhood evidence was employed simply because the jury would find these beliefs morally reprehensible. ${ }^{58}$

Justice Thomas filed a vigorous dissent, reasoning that even "abstract beliefs" can be relevant to the issue of "bad' character," which the Court's past rulings had deemed broadly provable for sentencing purposes. ${ }^{59}$ In addition, he urged that Dawson's gang membership was relevant for reasons that went beyond establishing his “"abstract' racist 'beliefs." ${ }^{60}$ In particular, Justice Thomas argued, this evidence tended to demonstrate that Dawson "had engaged in some sort of forbidden activities while in prison"; to prove his "future dangerousness"; and "to rebut [his] attempt to show that he was kind to others." ${ }^{1}$ Justice Thomas reasoned that jurors could draw on "their knowledge of the world" in assessing this evidence, especially because "[t]he concept of a prison gang is not so mysterious that it requires an encyclopedic definition." 62

Responding to these observations, Chief Justice Rehnquist questioned whether, in fact, "jurors would be familiar with" the nature of prison gangs and concluded that the unembellished "Aryan Brotherhood evidence ... cannot be viewed as relevant 'bad' character

\footnotetext{
55. Id. (noting "the narrowness of the stipulation").

56. Id. at 166 .

57. Id. at 165 .

58. Id. at 167 (citation omitted).

59. Id. at 176, 178 (Thomas, J., dissenting) (quoting $i d$. at 168 (majority opinion)).

60. Id. at 171 (quoting $i d$. at 167) (majority opinion).

61. Id.

62. Id.
} 
evidence in its own right." ${ }^{13}$ For Justice Thomas, however, this line of analysis served only to "bend traditional concepts of relevance." ${ }^{64}$ And this bending, for him, was especially problematic because he viewed the majority opinion itself as endorsing the admissibility of past-speech evidence so long as it is relevant ${ }^{65}$ In fact, however, the Chief Justice never embraced that position. Rather, he simply observed that a stronger showing of relevance would "have made this a different case" and "might have avoided" the constitutional problem the Court had detected. ${ }^{66}$

The bottom line is that the Court's three key rulings on speechbased evidence have not removed - and instead have highlighted - the doctrinal indeterminacy that pervades this subject. The Court has set forth no legal test for assessing the admissibility of past-speech evidence. Nor has it even begun to suggest how this set of cases fits within the overarching structure of its now-elaborate free-speech jurisprudence. Indeed, as discussed above, only Haupt concerned an objection to the admissibility of evidence that the Court viewed (to use the words of Dawson) as having some "bearing on the issue being tried." ${ }^{67}$ Without question, Haupt signals-as Dawson later confirmed - "that the Constitution "does not erect a per se barrier" against the use of past-speech evidence. ${ }^{68}$ But this proposition is neither controversial nor enlightening as to the key question considered in this

63. Id. at 168 (majority opinion).

64. Id. at 174 (Thomas, J., dissenting).

65. See id. at 179-80.

66. Id. at 167-68 (majority opinion). See also, e.g., J. Christopher Naftzger, Note, The Admissibility of First Amendment Protected Conduct as an Aggravating Factor in Capital Sentencing Trials After Dawson v. Delaware, 29 WILlameTtE L. REV. 343, 363 (1993) ("Dawson ... did little to establish a concrete rule concerning what constitutionally protected conduct is admissible as aggravating evidence during the penalty phase of a capital trial."). In addition, even Dawson's pronouncement about the absence of a "per se barrier" was targeted only "at sentencing." Dawson, 503 U.S. at 165. Thus, even if that statement somehow was meant to give rise to an admission-friendly, just-show-relevance principle, that principle would not necessarily apply to trial (as opposed to sentencing) proceedings, in light of the especially generous rules of admissibility that have long been applied in the sentencing context. See, e.g., Payne v. Tennessee, 501 U.S. 808, 820-21 (1991). Standing this idea on its head, one court has raised the possibility that any limit that Dawson imposes on the use of evidence in sentencing proceedings might properly be deemed inapplicable to trial proceedings, thus negating the operation of the First Amendment altogether in the trial context. Boyle v. Johnson, 93 F.3d 180, 185 n.9 (5th Cir. 1996). This suggestion, however, has things exactly backwards, in light of the law's distinctive evidentiary permissiveness in sentencing proceedings. See FED. R. EVID. 1101(d)(3) (specifying that evidence rules do not apply in sentencing proceedings).

67. Dawson, 503 U.S. at 168.

68. Id. at 165 . 
Article: To what extent does the First Amendment block prosecutorial use of a defendant's past speech at trial, even if it is relevant and otherwise admissible under the rules of evidence?

\section{The Lower Courts}

Not surprisingly, given the pervasiveness of both communicative activity and its routine use by prosecutors as inculpatory proof, lower courts have encountered a wide array of cases in which defendants raised First Amendment objections to the use of past-speech evidence. In response, some courts-especially before Dawson-signaled the need for serious-minded consideration of constitutional objections, regardless of evidentiary relevance ${ }^{69}$ But most courts, especially in recent years, have taken a different view, concluding - often based on Dawson - that the First Amendment never forecloses the use of pastspeech evidence so long as it is relevant. ${ }^{70}$ Given the centrality of the

69. See, e.g., Feminist Women's Health Ctr., Inc. v. Mohammad, 586 F.2d 530, 543, n.7 (5th Cir. 1978) (excluding evidence because "[i]ts evidentiary value... is far outweighed by the defendants' first amendment interests"); U.S. Football League v. Nat'l Football League, 634 F. Supp. 1155, 1171 (S.D.N.Y. 1986) (deeming "low probative value" to be "substantially outweighed by the defendants' strong interest in preserving their First Amendment rights"); United States v. Johns-Manville Corp., 259 F. Supp. 440, 453 (E.D. Pa. 1966) ("[I]t is within the province of the trial judge to exclude ... evidence if he finds that it is not probative or is unduly prejudicial."); Ayers v. State, 645 A.2d 22, 39 (Md. 1994) (seeming to deem past-speech evidence inadmissible unless "[a]t a minimum" it is "contemporaneous with the crime" or "part of the chain of events that led to the crime"); see also United States v. Ring, 706 F.3d 460, 473 (D.C. Cir. 2013) (recognizing the possibility that there is a need to "plac[e] a thumb" on the Rule 403 scale to safeguard "First Amendment concerns"); United States v. Curtin, 489 F.3d 935, 961 (9th Cir. 2007) (Kleinfeld, C.J., concurring) ("Barring exceptional circumstances, ... what people read ... should not be used to prove what they intend to do."); Weit v. Cont'l Ill. Nat'l Bank \& Tr. Co., 641 F.2d 457, 467 (7th Cir. 1981) (excluding evidence under Rule 403 based on "the First Amendment right to petition which Noerr-Pennington protects"); Tattered Cover, Inc. v. City of Thornton, 44 P.3d 1044, 1055 (Colo. 2002) (applying strict scrutiny in assessing a First Amendment objection to a subpoena of a bookstore purchase record without questioning its evidentiary relevance); Nickerson, supra note 6, at 864 (noting that "courts have employed a variety of multipart tests" that take account of the "defendant's ... First Amendment interests" in an effort to secure evidence about the identity of people who have made anonymous Internet postings).

70. See Anderson, supra note 5, at 927 (noting that "many...cases... reduce the constitutional issue to one of relevance"); see e.g., United States v. Rembert, 851 F.3d 836, 83839 (8th Cir. 2017) (affirming the district court's conclusion that a relevant Facebook video was admissible), cert. denied, 138 S. Ct. 401; United States v. Pierce, 785 F.3d 832, 840-41 (2d Cir. 2015) (highlighting that the defendant's First Amendment rights were not implicated when the district court found a rap video and tattoos admissible as evidence for the prosecution); United States v. Walters, 350 F. App'x 826, 829 (4th Cir. 2009) ("The First Amendment does not bar evidence of a person's associations when it provides a link to criminal activity."); Dressler v. McCaughtry, 238 F.3d 908, 915 (7th Cir. 2001) (disagreeing with the defendant's First Amendment claim, and highlighting that "the jury was permitted to draw an inference about [the 
relevance concept to evidence law, these decisions may also suggest a sensitivity to the generally applicable character of that law. ${ }^{71}$ On this view, because the basic relevance test of admissibility applies across the board to evidence of all kinds, there is no good reason to meddle with that rule on constitutional grounds simply because a small number of its applications involve the potentially prejudicial use of past-speech proof. $^{72}$

defendant's] state of mind based on the fact that he maintained a collection of photographs"); Boyle v. Johnson, 93 F.3d 180, 184 (5th Cir. 1996) (reasoning that "Dawson simply requires that the evidence be relevant" (citation omitted)); United States v. Beasley, 72 F.3d 1518, 1527 (11th Cir. 1996) ("A person's beliefs, superstitions, or affiliation with a religious group is properly admissible where probative of an issue in a criminal prosecution." (citations omitted)); United States v. Barnett, 667 F.2d 835, 844 (9th Cir. 1982) ("[T]he [F]irst [A]mendment does not compel the exclusion of evidence simply because it consists of speech. If a defendant's words or his silence are relevant to prove some issue in the case, they are admissible subject to the rules of evidence....”); State v. Rizzo, 833 A.2d 363, 446 (Conn. 2003) (holding that even if the defendant's statement constituted protected speech, "[it] was still admissible because it was relevant"); State v. Moore, 927 P.2d 1073, 1090 (Or. 1996) ("[U]nder Dawson, the trial court's admission of the evidence at issue here did not violate defendant's First Amendment rights."). Some lower courts also have found support for this position in Wisconsin v. Mitchell, 508 U.S. 476 (1993), based on the Court's observation that "[t]he First Amendment ... does not prohibit the evidentiary use of speech to establish the elements of a crime or to prove motive or intent." Id. at 489. This passage, however, in no way establishes that the First Amendment always requires admission of past-speech evidence so long as it is relevant. A mother might well say, for example, "I do not prohibit my ten-year-old from riding her bicycle on roadways." To make such a pronouncement, however, does not mean that the mother does not ever prohibit her ten-year-old from riding on roadways - for example, she might restrain her child from weaving through traffic on Fifth Avenue or from pedaling down a dark desert highway (and, all the more so, "a dark desert highway" to the Hotel California!). See THE EAGLES, Hotel California, on HotEL CALIFORNIA (Asylum Records 1976). A reading of Mitchell that comports with this interpretive principle makes especially good sense in light of the context of that case. As noted below, the defendant's argument in Mitchell stemmed from the idea that prosecutions under the challenged hate-crime law would broadly lead to the improper use of past-speech evidence. See infra notes 114-18 and accompanying text. One (entirely proper) response of the Court was to challenge the premise of this argument by noting that under Haupt and Dawson, many uses of past-speech evidence are totally proper. But saying that many uses of such evidence are totally proper is a far cry from saying that all uses of such evidence are totally proper. See also Mitchell, 508 U.S. at 489 (reiterating the Haupt Court's insistence that such evidence "be scrutinized with care"). The broader point is that Mitchell simply did not present the question whether all First Amendment objections to relevant past-speech evidence should be barred. See infra notes 115-18 and accompanying text. And even if the Court somehow meant to declare-however oddly and obliquely - that all free-speech-based challenges to proffers of relevant past-speech evidence were henceforth verboten, the significance of such a proclamation deserved, and still deserves, more thoughtful treatment than a one-sentence dictum.

71. See, e.g., Eugene Volokh, Speech as Conduct: Generally Applicable Laws, Illegal Courses of Conduct, "Situation-Altering Utterances," and the Uncharted Zones, 90 CORNELL L. REV. 1277, 1283 n.2, 1315, 1340-41 (2005) (noting the distinctive character of cases that only involve freespeech-evidence issues in discussing generally applicable laws).

72. See, e.g., Elena Kagan, Private Speech, Public Purpose: The Role of Governmental Motive 
Is this unwaveringly accommodating approach to the use of relevant past-speech evidence justifiable? We have already seen that it is not justifiable as a matter of stare decisis; in particular, the Court's rulings in Dawson and other past cases do not command this approach. But reaching that conclusion merely highlights the more basic question as to what governing rules should operate in this set of cases. Working through this matter brings into focus three more-particularized questions: First, precisely what is it about past-speech evidence that creates difficulties with its use under Free Speech Clause principles? Second, how do constitutional doctrines dealing with generally applicable laws-and the policies that underlie those doctrinesintersect with disputes about the admissibility of past-speech evidence? And third, if the First Amendment requires judges to police the use of otherwise relevant past-speech proof, what governing limits does that Amendment impose? The remainder of this Article explores these questions.

\section{First AmEndment VALues AND PAST-SPEeCh EVIDENCE}

Courts routinely receive into evidence out-of-court statements made by criminal defendants. These statements range from confessions obtained by law enforcement authorities to electronically intercepted conspiratorial communications to boasts made to friends about having committed a crime. Few analysts would suggest that the First Amendment requires exclusion of evidence of this kind. But given that fact, how should courts identify the types of past-speech evidence that might qualify for exclusion based on free-speech principles? Working through this conundrum requires courts to direct attention to an important body of post-Haupt law.

In a long and strong line of modern decisions, the Court has declared that the Constitution affords "special protection" to speech that addresses "matters of public concern." 73 This protection comports with the First Amendment's core objective of ensuring the "robust debate of public issues," 74 and all the more so because "speech

in First Amendment Doctrine, 63 U. CHI. L. REV. 413, 461-62 (1996) (noting, with regard to breach-of-the-peace laws, that their application "not only to speech, but also to conduct posing a risk of disorder" carries with it a "breadth [that] usually decreases... the chance of illicit[, viewpoint-repressive governmental] purpose").

73. Snyder v. Phelps, 562 U.S. 443, 453, 458 (2011).

74. Id. at 452 (quoting Dun \& Bradstreet, Inc. v. Greenmoss Builders, Inc., 472 U.S. 749, 760 (1985)). 
concerning public affairs is more than self-expression; it is the essence of self-government." " 5 Stated otherwise, protecting speech on matters of public concern directly advances the First Amendment's most salient (or least controversial) overarching aims - namely, to foster a well-functioning participatory democracy and to facilitate the search for truth on matters of the highest importance to society as a whole. ${ }^{76}$ There is a less apparent point, too. Protecting highly provocative speech on political and social matters - that is, the sort of speech that is the primary subject of investigation in this Article-links up in a special way with ensuring that citizens are afforded the chance to pursue individual self-realization through communicative activity. ${ }^{77}$ This is the case because not many citizens are willing to bear the social, and perhaps legal, costs of "putting themselves out there" as speechwielding, counterculture iconoclasts. ${ }^{78}$ And if they are, the very radicalism that leads them to incur such costs seems likely to be tied tightly to a core sense of self. ${ }^{79}$

Against this backdrop, the Court has chosen to give "broad protection" to speech on matters of public concern..$^{80}$ It has done so in part by defining that term expansively to include all expression that can "be fairly considered as relating to any matter of political, social, or other concern to the community." ${ }^{81}$ It does not matter that the "contribution to public discourse" of a particular item of such speech "may be negligible." 82 It is also of no consequence that such an

75. Id. (quoting Garrison v. Louisiana, 379 U.S. 64, $74-75$ (1964)).

76. KATHLEEN M. SULLIVAN \& NOAH FELDMAN, CONSTITUTIONAL LAW 935-40 (19th ed. 2016).

77. See id. at $938-39$.

78. Ho Hwan Park, Youjia Zhou \& Myungweon Choi, When Are Individuals Innovative?, 17 J. PERSONNEL PSYCHOL. 1 (2018) ("Conscientious individuals tend to follow rules, conform to norms, be cautious and risk averse, and strictly adhere to standards; thus, they are less likely to come up with new ideas and change the status quo.").

79. Suggestive of the pressures described here, and of the self-actualizing responses one might make to them, is an iconic, though cryptic, counterculture anthem of the early 1970s. See DAVID CROSBY, Almost Cut My Hair, on DÉJÀ VU (Atlantic Records 1970). In it, the singerhimself a counterculture icon-describes the choice made when "I almost cut my hair." Id. Ruminations that crop up in the song concern "paranoia" connected with the possibility of "lookin' in my mirror and seeing a police car." Id. But the hair, in the end, remains unscissored. $I d$. Despite the risks of having unconventionally long hair, the singer in the end concludes, "I'm not givin' in an inch to fear" because "I feel like letting my freak flag fly." Id.

80. Snyder, 562 U.S. at 452 (internal quotation marks omitted).

81. Id. at 453 (quoting Connick v. Myers, 461 U.S. 138, 146 (1983)).

82. Id. at 460 . 
utterance is "inappropriate or controversial" 83 or "arouses contempt." ${ }^{84}$ To the contrary, "in public debate [we] must tolerate insulting, and even outrageous, speech." ${ }^{85}$ These principles are so vibrant that the Court has drawn on them to deem such pronouncements as "God hates the USA/Thank God for 9/11," "Thank God for Dead Soldiers," and "Pope in Hell" as embodiments of speech on matters of public concern. ${ }^{86}$

In addition to defining the notion of public-concern speech broadly, the Court has seized on this concept to safeguard expression in many different legal settings. These rulings stretch across defamation $\operatorname{law}^{87}$ to the tort of intentional infliction of emotional distress $^{88}$ to statutes that limit media reports of purportedly

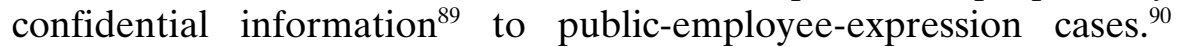
Along the way, the Court has declared without reservation that speech on matters of public concern "occupies the highest rung of the hierarchy of First Amendment values."91

Courts accordingly must take account of public-concern-speech doctrine as they grapple with First Amendment limits on the use of expression-related evidence. Indeed, public-concern-speech doctrine bears on the formulation of those limits in two distinct ways. First, this body of law provides a previously endorsed, and thus ready-to-use, touchstone for separating speech-related evidence that is worthy of First Amendment scrutiny from speech-related evidence that is notsuch as speech in the form of confessions and crime-planning conversations. Second, the public-concern-speech doctrine now operates with much force in many cases, including many civil cases.

83. Id. at 453 (quoting Rankin v. McPherson, 483 U.S. 378, 387 (1987)).

84. Id. at 458 .

85. Id. (quoting Boss v. Barry, 485 U.S. 312, 322 (1988)).

86. Id. at 454 (citation omitted).

87. See Gertz v. Robert Welch, Inc., 418 U.S. 323, 342 (1974).

88. See Snyder, 562 U.S. at 443.

89. See Bartnicki v. Vopper, 532 U.S. 514, 534-35 (2001); see also Morse v. Frederick, 551 U.S. 393, 422 (2007) (Alito, J., concurring) (identifying a special need to protect public-school speech if it "can plausibly be interpreted as commenting on any political or social issue").

90. Rankin v. McPherson, 483 U.S. 378, 392 (1987). A particularly significant publicemployee-speech case is Connick v. Myers, 461 U.S. 138 (1983), which is discussed at some length infra notes 232-42.

91. Snyder, 562 U.S. at 452 (quoting Connick, 461 U.S. at 145); see also Engquist v. Or. Dep't of Agric., 553 U.S. 591, 600 (2008). All these decisions comport with a broader point, too-in many contexts, going back many years, the Court has emphasized that speech on political and social issues rests at "the core of the First Amendment." NAACP v. Claiborne Hardware Co., 458 U.S. 886, 926-27 (1982) (describing "highly charged political rhetoric" this way). 
And if public-concern speech merits this sort of "broad protection" in civil law, it becomes hard to see why it should receive no serious scrutiny when it is offered as evidence to secure criminal convictions that might lead to years of imprisonment or even death. ${ }^{92}$

One possible response to this line of analysis posits that whether or not public-concern speech is in the picture, the government cannot be regarded as "abridging the freedom of speech"-as proscribed by the text of the First Amendment-unless it moves to sanction speech itself, such as by making speech with specific characteristics the actus reus of a crime. It is well settled, however, that the First Amendment sweeps more broadly than that. ${ }^{93}$ Indeed, Dawson removes any doubt on this score. As the Court there explained, "the reach of the First Amendment" often blocks the state from "criminalizing . . . conduct" that takes the form of speech..$^{94}$ But the Amendment "goes further than that," 95 including, in proper cases, by preventing the State from employing speech as evidence. ${ }^{96}$

Dawson thus confirms what many other cases suggest-namely, that prosecutorial deployments of past-speech evidence "burden,"97 "impair," that brings the First Amendment into play. To be sure, courts might nonetheless embrace a constitutional rule that allows all uses of past speech "just" or "simply" as evidence so long as that evidence surpasses the minimum threshold of relevance. ${ }^{100}$ Such a sweeping exemption from any constitutional protection, however, is hard to square with the idea that such uses of speech impose cognizable First Amendment burdens on defendant-declarants. And this conclusion becomes even more compelling when it is recognized that prosecutorial use of past-speech evidence encroaches on free-expression rights in no fewer than three separate ways: (1) by exposing defendants to

92. But cf. United States v. Herron, No. 10-CR-0615, 2014 WL 1871909, at *2-3 (E.D.N.Y. May 8, 2014) (dismissing the Court's protection of public-concern speech in Snyder as inapplicable in the past-speech-evidence context).

93. See, e.g., NAACP v. Alabama ex rel. Patterson, 357 U.S. 449, 466 (1958) (holding that forced disclosure of a membership list abridged members' speech rights, even though those disclosures did not subject the members to governmentally imposed criminal or civil sanctions).

94. Dawson v. Delaware, 503 U.S. 159, 168 (1992).

95. Id.

96. Id.; see also Anderson, supra note 5, at 929 (emphasizing this point).

97. Madsen v. Women's Health Ctr., Inc., 512 U.S. 753, 765 (1994).

98. Shelton v. Tucker, 364 U.S. 479, 485 (1960).

99. NAACP v. Alabama ex rel. Patterson, 357 U.S. 449, 462 (1958).

100. Volokh, supra note 71 , at $1315,1340$. 
conviction based on the factfinder's unfairly prejudicial consideration of such speech; (2) by subjecting defendants to convictions based on such speech even in the absence of unfair prejudice; and (3) by chilling provocative expression by defendants and by others as well.

\section{A. Convictions Based on Unfair Prejudice}

The Government's use of past-speech evidence burdens that speech, first and foremost, because that evidence might well come to weigh on the minds of jurors for legally impermissible reasons. Trials are complex affairs. Jurors find themselves in an unfamiliar setting. Judges provide them with instructions before, during, and after the submission of evidence. Jurors must sift through large amounts of information. But when they learn that the defendant is a Nazi or a Klansman, that information is likely to stick in their minds. Such evidence-at least for most-is jarring, hurtful, and deeply disturbing. ${ }^{101}$ Thus, "[i]n a case such as this, a jury is unlikely to be neutral with respect to the content of [the] speech, posing a real danger of becoming an instrument for the suppression of ... vehement, caustic, and sometimes unpleasan[t] expression." ${ }^{102}$

Whenever a trial judge admits past-speech evidence, it is-like all evidence-admissible only for specific purposes. As the Introduction to this Article shows, for example, such evidence might help to show that the defendant committed a criminal act by suggesting the existence of an underlying motive for engaging in that behavior. Jurors, however, might view motive-related evidence as showing something more-a lack of honor, reason, or restraint; future unpredictability; or outlandish foolishness. ${ }^{103}$ Those charged with factfinding might conclude, in other words, that the defendant is bad, radical, or weird and deserving of punishment for that reason. ${ }^{104}$ The mysteries of

101. See, e.g., United States v. Roark, 924 F.2d 1426, 1434 (8th Cir. 1991) (finding that proof of one defendant's connection to the Hell's Angels motorcycle organization brought such a risk of prejudice in a methamphetamine-manufacturing prosecution that the conviction must be reversed in case the jury had deemed the defendant "guilty by association," notwithstanding a limiting instruction).

102. Snyder v. Phelps, 562 U.S. 443, 458 (2011) (internal quotations and citation omitted).

103. See, e.g., FED. R. EVID. 404. See also Quint, supra note 2, at 1658 n.81 (noting the "particular dangers" of juries' assessments of this kind because of their built-in "majoritarian" cast and lack of sensitivity to systemic free-speech values).

104. See, e.g., Stuart P. Fischoff, Gangsta' Rap and a Murder in Bakersfield, 29 J. APPLIED SOC. PSYCHOL. 795, 797 (1999) (noting expert testimony that juries use rap lyrics to reach guilty verdicts improperly because of "negative personality trait associations conjured up by such inflammatory lyrics"). 
psychological analysis make it difficult to say that all jurors in all circumstances ignore such appraisals of character in the decisionmaking process, even when they are instructed to do just that. ${ }^{105}$ Indeed, this is a major reason why the use of character evidence has long been subjected to far-reaching limitations under general evidence law principles. ${ }^{106}$ Nor can community-representing juries be counted on to avoid improper condemnation of political and social dissidents. The radical nature of the speech of such persons, after all, almost certainly will brand them as outliers within the very communities from which jurors are drawn. To be sure, some community members may share or sympathize with the worldviews of steely-edged naysayers. The more likely it is that prospective jurors do so, however, the more likely it is that they will be excluded from jury service from the outset through the use of peremptory strikes.

Most important of all, to the extent that speech-driven, characterrelated considerations improperly come into play in the course of the jury's work, the burden placed on protected speech is both obvious and profound. The difficulty, as Justice Oliver Wendell Holmes once declared, is that "defendants are to be made to suffer not for what the indictment alleges but for the creed that they avow." ${ }^{107}$ Professor Quint captures this concern in these words:

Whenever evidence of unpopular but protected speech or association is introduced against a criminal defendant, the jury may make improper use of that evidence by penalizing the exercise of First Amendment rights. In a criminal trial, the jury as a constituent of the court exercises the power of the state. Hence, the improper penalization of protected speech by a jury violates the First

105. See Quint, supra note 2, at 1648 n.81, 1666 (developing the point that "limiting... instructions are ineffective as a prophylactic technique," and quoting Justice Jackson's observation that "[t]he naive assumption that prejudicial effects can be overcome by instructions to the jury... all practicing lawyers know to be unmitigated fiction" (quoting Krulewitch v. United States, 336 U.S. 440, 453 (1949) (Jackson, J., concurring))). See generally Roselle L. Wissler \& Michael J. Saks, On the Inefficacy of Limiting Instructions, 9 LAW \& HUM. BEHAV. 37 (1985) (discussing how juries use criminal-record evidence against defendants, even when such evidence is designed only to impeach a witness's credibility).

106. See, e.g., FED. R. EVID. 404 advisory committee's note (highlighting that rules on character evidence are "deeply imbedded in our jurisprudence" and that such evidence faces limitations because it has "slight probative value and may be very prejudicial"; and further, emphasizing that character evidence "tends to distract the trier of fact from the main question of what actually happened ... [and] subtly permits the trier of fact to reward the good man and to punish the bad man because of their respective characters despite what . . actually happened").

107. Abrams v. United States, 250 U.S. 616, 629 (1919) (Holmes, J., dissenting). 
Amendment to the same extent as analogous action by any other governmental entity. ${ }^{108}$

The essential idea is that the use at trial of past-speech evidence often creates a perilously high danger of unfair prejudice to the defendant-unfair in the sense that the factfinder may well consider the evidence for reasons that go beyond its proper use as evidence, thus disadvantaging the defendant because of protected beliefs, associations, or statements. In other words, the introduction of pastspeech evidence places a burden on speech by threatening to generate an improperly obtained conviction. Indeed, the inherent tendency of past-speech evidence to prejudice the defendant means that all cases involving its use present the very same danger highlighted in Dawsonnamely, that decisions adverse to criminal defendants will be driven by reasons that should have "no bearing on the issue being tried."109

\section{B. Convictions Based on "Fair Prejudice"}

As the foregoing analysis suggests, Professor Quint focuses on the danger of "unfair prejudice" in arguing for careful judicial review of prosecutorial use of past-speech evidence. So, too, do other analysts. ${ }^{110}$ The risk of unfair prejudice arises because of the possibility that the factfinder may rely on part of the prosecutor's evidentiary submission in a way that is inconsistent with the rules of evidence. But prosecutorial use of past-speech evidence presents an additional problem: Even when that evidence is not unfairly put to work, it still operates to establish the defendant's guilt, particularly when the defendant otherwise might have been found not guilty. As a result, the government's actions cause the defendant's past engagement in wholly protected speech to operate to the extreme detriment of the defendant. Thus, earlier critics of wide-open use of past-speech evidence have missed, or at least underemphasized, a significant point: the use of past-

108. Quint, supra note 2, at 1641.

109. Dawson v. Delaware, 503 U.S. 159, 168 (1992). To be sure, some analysts may argue that prosecutorial use of "unfairly prejudicial" evidence with some, though perhaps only minimal, relevance is more justifiable than the use of "unfairly prejudicial" evidence that, as the majority seemed to see things in Dawson, fails to cross the relevance line. But regardless of this point, the burden placed on the defendant's speech in both cases is the same - that is, the disadvantage that arises because the jury may rely on that speech for unfairly prejudicial, and thus impermissible, purposes.

110. See, e.g., Laura K. Donohue, Terrorist Speech and the Future of Free Expression, 27 CARDOZO L. REV. 233, 324-26 (2005); Faulkner, supra note 5, at 20 ("[B]y far the greatest danger is that the truth-seeking function ... will be compromised ...."). 
speech evidence burdens expression rights even if a jury considers it in wholly Simon-pure fashion - that is, in a way that is entirely proper for the purposes of evidence law standing alone.

To review the basics, only relevant evidence is admissible at trial. Thus, the admission of past-speech evidence necessarily means that the judge has found it to be probative as to some factual issue in the case. As a result, to the extent that a factfinder considers the evidence only in resolving that issue, the factfinder will not have used the evidence in a way that is unfairly prejudicial. Even in these circumstances, however, past speech is being used against the defendant, and for this reason prosecutorial use of past-speech evidence is problematic "in and of itself." 111 In other words, one burden on expression that arises from the use of past-speech evidence involves what might be called "fair prejudice," and this burden is borne by defendants in two separate ways. First, the fair-prejudice burden arises because prosecutorial and judicial actions put the past-speech evidence before the jury for the very purpose of inviting the jury to view that evidence as tending to show the defendant's guilt. In other words, the Government's use of the evidence is bad for the defendant, and that bad result arises only because the defendant engaged in protected speech in the past.

Second, in some cases, the use of past-speech evidence-even in the absence of unfair prejudice-burdens the defendant in the most profound of ways because it proves decisive to the jury's finding of guilt. In these cases, use of the evidence stands in the starkest tension with the core First Amendment principle that, when the government considers taking action against an individual, that individual "should not have the . . q question resolved against him because of constitutionally protected conduct." ${ }^{112}$ The difficulty is apparent. If past-speech evidence is the straw that breaks the camel's back in generating a successful prosecution, the government will have secured the defendant's punishment because of the defendant's past protected speech in a direct and obvious sense. ${ }^{133}$ By definition, after all, but-for causation is present when one thing-here, the submission of pastspeech evidence - is decisive in bringing about a particular outcomehere, the conviction of the defendant.

111. Dennis, supra note 4 , at 40 .

112. Mt. Healthy City Sch. Dist. Bd. of Educ. v. Doyle, 429 U.S. 274, 286 (1977).

113. Put another way, in such a case, the conviction not only "may have rested on a form of expression, however distasteful, which the Constitution tolerates and protects." Street v. New York, 394 U.S. 576, 594 (1969). Instead, in such a case, the conviction does rest on such expression in a decisive, but-for sense. 
To be sure, for almost all lawyers and judges, it would be too extreme to say that this but-for-causation problem requires in all cases the exclusion of relevant past-speech evidence. But that does not change the fact that this but-for-causation problem exists. To be sure, many judges may deem the burden that arises from the fair-prejudice effects of using past-speech evidence-including its potential but-forcausation effects - to be less worrisome than the burden that arises from the risk of unfair prejudice. Even if that view of things is sound, however, the fair-prejudice problem is real. And as a result, the fairprejudice burden on speech should count for something-and perhaps count significantly - when courts work to accommodate individual rights and societal needs as the two come into conflict in this set of cases.

\section{Chilling Effects}

A third burden imposed by prosecutors' leveraging of past-speech evidence involves chilling effects. In particular, using public-concern speech as inculpatory evidence threatens to stifle such speech not only by criminal defendants themselves, but also by social outsiders of all stripes. Notably, the chilling-effects problem posed by authorizing the use of speech as evidence is very different from the problem posed by the direct prohibition of communicative activity. This is so because a person who makes statements that are themselves entirely legal may be slow to consider the prospect that those statements could be used as inculpatory evidence in a later proceeding that does not involve prosecution for the statements themselves. The Court made this very point in Wisconsin v. Mitchell, deeming it "speculative" to assume that a would-be speaker might think through things in this way. ${ }^{114}$ The following examination of Mitchell, however, reveals that the problem analyzed by the Court in that case was so specialized and distinct that it should not bear on formulating constitutional rules concerning the admissibility of past-speech evidence.

In particular, the Court in Mitchell confronted a facial challenge to a statute that required sentence enhancements for crimes motivated by bias regarding the victim's "race, religion, color, disability, sexual orientation, national origin or ancestry." 115 The case did not present any issue regarding the propriety of introducing speech-based evidence at trial to prove a prohibited discriminatory intent or to prove anything

114. Wisconsin v. Mitchell, 508 U.S. 476, 489 (1993).

115. Id. at 480 . 
else. Instead, the defendant in Mitchell argued that chilling-effects concerns, coupled with the First Amendment overbreadth doctrine, required invalidation of the challenged sentencing-enhancement law as a whole because some prosecutors might sometimes invoke the law to support the introduction of past-speech evidence about a defendant's biased views. ${ }^{116}$ Put another way, Mitchell involved an attack on each and every application of a substantive criminal restriction-indeed, a very common form of substantive restriction-based on an effort, novel in the extreme, to extend the overbreadth doctrine. ${ }^{117}$ One might even go so far as to conclude that the Court in Mitchell did nothing more than reach the most predictable of results - namely, by determining that the potential use of past-speech evidence in some cases does not warrant the wholesale invalidation of all forms of state and federal antidiscrimination laws. ${ }^{118}$ In any event, the Court never suggested that actual prosecutorial use in an actual case of politically or socially charged past-speech evidence creates no risk whatsoever of generating problematic chilling effects.

Nor should it have. As noted earlier, the Court in Mitchell observed that outright prohibitions on speech generate greater chilling-effect problems than trial-process rules under which utterances made today might be used as evidence sometime in the future. ${ }^{119} \mathrm{But}$ that does not mean that the evidentiary use of protected speech creates no chilling effects at all. ${ }^{120}$ At least some potential speakers contemplate the risk of future evidentiary use of their statements, especially if they are repeat players in the criminal justice system or already enmeshed in litigation. Others may hesitate to engage in boundary-pushing commentary because of a generalized, but still accurate, wariness that legal disadvantages lie in wait for agitators who

116. Id. at 488 .

117. The argument was novel in the extreme because the overbreadth doctrine authorizes the facial invalidation of a statute when "a substantial number of its applications are unconstitutional" in comparison to its "legitimate sweep." United States v. Stevens, 559 U.S. 460, 473 (2010). In Mitchell, however, the challenger did not argue that the hate-crime law was overbroad in this traditional sense. Instead, he argued that the statute was rightly viewed as overbroad because it might have the practical effect of causing the introduction into evidence of protected-speech activity, even if the statute itself outlawed only properly proscribable behavior. See supra note 116 and accompanying text.

118. Mitchell, 508 U.S. at 487 (reasoning that hate-crime laws are not functionally distinguishable from other antidiscrimination statutes).

119. See supra note 114 and accompanying text.

120. See Nickerson, supra note 6, at 871 (noting, in this regard, that "the absence of empirical evidence of a chilling effect" has not negated the Court's recognition of such effects); Quint, supra note 2 , at 1645-46 (developing the same point). 
do not hold their tongues. And that generalized wariness might well emanate in part from prosecutorial use of past speech as evidence.

Chilling effects may be particularly acute for specialized communities of speakers. In recent years, for example, the use of rap lyrics as evidence has generated widespread media coverage. ${ }^{121}$ Thus, the risk arises that some rap artists will water down the edginess of their lyrics because they know those lyrics might later be used as evidence against them. Indeed, other legal analysts (who know much more about rap music than I do) have concluded that this risk is very real. ${ }^{122}$

Against this backdrop, it is not surprising that thoughtful commentators-including First Amendment luminary Thomas I. Emerson-have concluded that the evidentiary use of past speech causes problematic chilling effects. ${ }^{123}$ Moreover, the danger presented

121. See, e.g., Adam Dunbar, Rap on Trial: Do Violent Lyrics Prove a Crime, CRIME REP. (Aug. 7, 2017), https://thecrimereport.org/2017/08/07/rap-on-trial-do-violent-lyrics-prove-a-crime [https://perma.cc/M2RT-E4NF]; Lorne Manly, Legal Debate on Using Boastful Rap Lyrics as a Smoking Gun, N.Y. TIMES (Mar. 26, 2014), https:/www.nytimes.com/2014/03/27/arts/music/ using-rap-lyrics-as-damning-evidence-stirs-legal-debate.html [https://perma.cc/DZ9X-SF4X]; Erik Nielson, 'Rap on Trial': Why Lyrics Should Be Off-Limits, Rolling STONE (May 3, 2017, 8:05 PM), https://www.rollingstone.com/culture/culture-news/rap-on-trial-why-lyrics-should-beoff-limits-116368 [https://perma.cc/ELB5-R8L3]; Alyssa Rosenberg, How Cops and Prosecutors are Putting Rap Music on Trial, WASH. Post (May 21, 2014), https:/www.washingtonpost.com/ news/act-four/wp/2014/05/21/how-cops-and-prosecutors-are-putting-rap-music-on-trial/?utm _term=.cf831aa761b1 [https://perma.cc/7TMJ-9H9S]; Kay Wicker, Amateur Rap Lyrics Are Being Used as Evidence Across the Country, THINKPROGRESS (Sept. 1, 2017, 10:30 AM), https://thinkprogress.org/rap-lyrics-evidence-texas-acb3870f7d2c [https://perma.cc/QS7R-JRSV].

122. See Dennis, supra note 4, at 5, 40 (noting the "negative impact [that use of rap music as evidence] will have on the production and quality of art"); Jason E. Powell, Note, R.A.P.: Rule Against Perps (Who Write Rhymes), 41 RUTGERS L.J. 479, 499 (2009) (citing views of practicing lawyers that "using rap lyrics as evidence will ... lead to mundane, unprovocative art"); $i d$. at 515-16 ("When courts use creative devices as evidence of their creator's knowledge or intent to commit a crime, the result is a chilling effect... [including] a chilling effect on the rap music genre.").

123. Emerson describes the problem of chilling effects as follows:

[E]xpression may be seriously inhibited when the speaker knows that what he says can be used against him at a later time if some unforeseen action ensues, can be taken into account by a jury in determining his state of mind in performing a subsequent act, or can perhaps be the decisive factor in a jury's general verdict against him.

THOMAS I. EMERSON, THE SYSTEM OF FREEDOM OF EXPRESSION 405 (1970). See also Anderson, supra note 5, at 902 (urging that "the potential for a chilling effect on listeners' rights under the First Amendment" based on the compelled provision of evidence "is very real"); Faulkner, supra note 5, at 12; Edward J. Imwinkelried, The Meaning of Probative Value and Prejudice in Federal Rule of Evidence 403: Can Rule 403 Be Used to Resurrect the Common Law of Evidence?, 41 VAND. L. REV. 879, 890 (1988) (citing the prospect of individuals' fears that "constitutionally protected statements would come back later to haunt them"); Nickerson, supra note 6, at 847; Quint, supra note 2, at 1645-46 (noting chilling-effect concerns); Note, Conspiracy and the First Amendment, 79 YALE L.J. 872, 894 (1970) (same); Note, The First Amendment Overbreadth 
by these effects has risen significantly in recent decades with the explosion of modern communications technologies. One effect of those technologies is particularly significant: acts of expression today routinely take place on the Internet and are thus locked into a retrievable form. In similar fashion, even brief rants can be captured on cellphones and similar easy-to-use devices. The making of speech in such permanently recorded ways thus allows present-day prosecutors to discover and deploy past-speech evidence much more readily than prosecutors of the past. ${ }^{124}$ And this reality compounds the risk that would-be speakers will be deterred from engaging in full-throated dissent precisely because they know their words might well become available for use by the government, including as evidence, at a later time.

None of this means that under present conditions most Internet speakers steer clear of sharing extremist views in forms they otherwise would freely use. That is neither the case nor the point. The point instead is that there is reason to conclude that some speakers hold back in some circumstances to some degree, in part because what they say might later be used as evidence against them. This effect, in turn, strikes at the heart of the First Amendment because it involves the suppression of protected speech. Notably, the Court has never required a detailed empirical showing of the fact or the extent of these sorts of chilling effects. Instead, it has simply used its own common sense in concluding that certain forms of government action might well deter wide-open engagement in protected expression. ${ }^{125}$ That same approach suggests that, in this context, chilling-effect concerns have a role to play as courts decide how to handle past-speech evidence.

Doctrine, 83 HARV. L. REV. 844, 926 n.325 (1970) (same). For some judicial treatments, see Dawson v. Delaware, 503 U.S. 159, 169 (1992) (Blackmun, J., concurring) (noting "the potential chilling effect that consideration of First Amendment activity at sentencing might have") and United States v. Ring, 706 F.3d 460, 473 (D.C. Cir. 2013) (noting that "chilling' concerns" resulting from evidentiary use "are especially powerful where political speech is involved"). But see Dressler v. McCaughtry, 238 F.3d 908, 915 (7th Cir. 2001) (downplaying any "potential chilling effect").

124. See Dennis, supra note 4, at 40-41 (emphasizing the "exceedingly public" nature of the Internet and that "[1]aw enforcement and prosecutors will train their sights on ... widely accessible types of creative expression").

125. See infra note 120 and accompanying text. 


\section{FREE SPEECH, EVIDENCE, AND GENERALLY APPLICABLE LAWS}

As the foregoing discussion shows, prosecutorial use of pastspeech evidence places a burden-indeed, a complex, multipart burden - on protected expression. Even so, perhaps this burden should not give rise to any meaningful constitutional restraint. Part I of this Article shows, for example, that lower courts have read Dawson to foreclose the imposition of First Amendment limits on the use of relevant past-speech evidence. ${ }^{126}$ But Part I also demonstrates that this reading of Dawson is misguided. ${ }^{127}$ Is there another line of argument that thoughtful prosecutors might put forward as they urge courts to allow the use of all relevant past-speech evidence? One can imagine an argument that builds on the idea that generally applicable evidence law is not subject to Free Speech Clause challenges precisely because it is generally applicable in character. After all, generally applicable laws are, in their nature, far removed from laws that target speech itself. Of particular importance, the widespread operation of such laws, including against nonspeakers, provides assurance that the government put them in place for salutary reasons wholly unrelated to the burdening of constitutionally protected rights.

The poster child for this line of reasoning is Employment Division v. Smith. ${ }^{128}$ There, the Court relied on the generally applicable character of the law at issue to reject an as-applied Free Exercise Clause challenge to a ban on the use of peyote, which the individual who raised the challenge had ingested as a sacramental act. ${ }^{129}$ And Smith does not stand alone. The Court has relied on the generally applicable character of challenged laws to resist their invalidation in a number of cases that did not involve the Free Exercise Clause. ${ }^{130}$ None of this would matter if the Court had made clear that its hands-off treatment of generally applicable laws in other contexts had no role whatsoever to play in free-speech cases. But in one earlier case, Cohen v. Cowles Media Co., ${ }^{131}$ the Court suggested-albeit both controversially and confusingly-that the generally applicable

126. See supra note 70 and accompanying text.

127. See supra notes 48-68 and accompanying text.

128. Emp’t Div., Dep’t of Human Res. of Or. v. Smith, 494 U.S. 872, 890 (1990).

129. $I d$.

130. See Exxon Corp. v. Eagerton, 462 U.S. 176, 194 (1983) (applying the Contracts Clause); see also Washington v. Davis, 426 U.S. 229, 246-48 (1976) (refusing to apply heightened Equal Protection Clause scrutiny solely because of a law's minority-disadvantaging effects).

131. Cohen v. Cowles Media Co., 501 U.S. 663 (1991). 
character of a challenged law might, at least sometimes, exempt it from constitutional free-expression-based challenge. ${ }^{132}$

These authorities provide ammunition for those who believe that prosecutorial use of relevant past-speech proof should be allowedwith no constitutional limits-because evidence law is generally applicable in character. Evidence law, after all, does not target speech. Instead, it deals with all forms of evidence. In addition, the purposes of evidence rules have nothing to do with "the suppression of free expression"; ${ }^{133}$ rather, those rules focus on ensuring the fair, orderly, and well-informed resolution of factual disputes. ${ }^{134}$

Further, the law of evidence is generally applicable in a special way. The typical generally applicable law, such as the peyote ban at issue in Smith, has a one-way-street quality in that it imposes burdens that do not extend to the government. Put differently, such a law exposes only ordinary citizens to the limits and sanctions the government has imposed. The law of evidence, in contrast, simultaneously benefits and burdens both ordinary citizens and the government itself - for instance, by subjecting all parties in any trial to the rule that all relevant evidence is presumptively admissible against them. This dynamic might cause courts to hesitate to place First Amendment limits on the operation of evidence rules in a way that disadvantages only the State. Those judges might reason that given the two-way-street nature of the law of evidence, it is inappropriate to install a one-way-street constitutional restriction that limits the prerogatives only of government prosecutors. ${ }^{135}$ At the very least, some

132. Id. at 672. A later discussion of the Cohen case shows why this reading of it, even if superficially plausible, is unjustifiable. See infra notes 148-53 and accompanying text.

133. United States v. O’Brien, 391 U.S. 367, 377 (1968).

134. In addition, some policy reasons that support the Court's ruling in Smith seem applicable in the past-speech-evidence context. Just as in Smith, applying a bright-line rule, based on the doctrine of generally applicable laws, would ease the decision-making task in this context. A bright-line rule would also make it less likely that judges would smuggle personal considerations into the decision-making process. Indeed, one might say that the Smith principle should control, a fortiori, questions concerning the admissibility of past-speech evidence. On this view, Mr. Smith's spiritually inspired peyote use was itself the gravamen of the charged criminal offense. In free-expression-evidence cases, on the other hand, speech comes before the factfinder as just "one link in the long chain of evidence." See Dressler v. McCaughtry, 238 F.3d 908, 915 (7th Cir. 2001).

135. For a similar line of analysis advanced by Professors Akhil Reed Amar and Richard A. Nagareda regarding the Compulsory Process Clause, see infra note 141. Notably, however, the Amar-Nagareda position has been rejected by the Supreme Court. See id. Also cutting against this line of analysis is the practical reality that some evidence rules-such as the coconspiratordeclaration exception to the hearsay rule-apply overwhelmingly to the disadvantage of criminal defendants, and other evidence rules discriminate on their face against defendants and in favor of 
judges might say, the only properly recognized constitutional limit in this field should focus-à la Dawson-on evidentiary relevance, because such a limit reinforces, rather than undermines, the longrecognized generally applicable principle that all relevant proof is presumptively admissible at trial. ${ }^{136}$

This line of argument may have surface appeal. But it suffers from a fatal flaw. The problem is that the two-way-street argument fails to take account of the full body of the Court's jurisprudence on generally applicable law. and the policy concerns that have driven the Court's key precedents on general applicability. Indeed, four separate components of the Court's doctrine undermine the position that pastspeech evidence should be admissible, despite First Amendment protections, because of the generally applicable nature of evidence law: (1) the Court's past declaration that laws challenged on free-speech grounds - in contrast to laws challenged on free-exercise grounds, as in Smith-are not immune from constitutional attack because of their generally applicable character, ${ }^{137}$ (2) the Court's particular insistence that judicial review should be more exacting when generally applicable laws place "direct-in-effect" burdens-as opposed to merely "incidental" burdens-on protected speech:138 (3) the Court's insistence, even in the Smith case, that otherwise operative limits on judicial review do not apply when the challenged law, even though generally applicable, requires "individualized" governmental determinations about "eligibility" issues; ${ }^{139}$ and (4) the Court's longstanding endorsement of speech-protective "First Amendment

the Government. See, e.g., United States v. Santos, 372 F.2d 177, 180 (2d Cir. 1967) (detailing special limits on the use of admissions of government agents in criminal proceedings).

136. See, e.g., FED. R. EVID. 402.

137. See infra Part III.A. Putting to one side the Court's ruling in the Cohen case, see infra notes $147-53$ and accompanying text, there is one arguable exception to the proposition that laws burdening free speech are not immune from constitutional challenge merely because of their general applicability. The relevant limitation was recognized in a line of cases culminating in Arcara v. Cloud Books, Inc., 478 U.S. 697 (1986). There, the Court dealt with the application to a bookstore of a municipal ordinance that mandated a year-long closure of any business site on which "sexual activity" had occurred. $I d$. at 699 . The Court held that this law was not subject to any form of First Amendment review. Id. at 707. The Court's reasoning was that the target of the government's action was the lewd conduct - here, largely prostitution - which had "nothing to do with books or other expressive activity." Id. In contrast, the burden that is placed on the defendant-declarant in past-speech-evidence cases stems directly from that individual's past engagement in protected speech itself. Accordingly, Arcara is beside the point here.

138. See infra Part III.B.

139. See infra Part III.C. 
due process" restrictions, including in cases that involve the Government's use of evidence. ${ }^{140}$

It merits emphasis that none of these four means of avoiding Smith's general-applicability reasoning is farfetched in this context; indeed, each one has its origins in settled precedent and has much to be said in its favor. Even more important, the underlying reasons that have given rise to each of the lines of precedent support the case for meaningful First Amendment scrutiny of past-speech evidence. In sum, four already-established bodies of general-applicability doctrine, especially when viewed as a whole, offer powerful justifications for imposing significant constitutional limits on the evidentiary use of past protected expression. ${ }^{141}$

140. See infra Part III.D.

141. There is a fifth line of cases-distinguishable from the four discussed in the text because it has no direct connection to the First Amendment - that supports this same pro-defendant view. In these cases, the Supreme Court has held that judges sometimes must override generally applicable evidence rules related to privilege, hearsay, and the like, so as to admit otherwise inadmissible evidence and thereby vindicate the criminal defendant's constitutional rights. 2 EDWARD J. IMWINKELRIED, THE NEW WIGMORE: A TREATISE ON EVIDENCE: EVIDENTIARY PRIVILEGES $\S 11.2 .1$ (Richard D. Friedman ed., 3d ed. 2017). Illustrative is the extent to which the defendant's Sixth Amendment right to compel attendance of "witnesses in his favor" trumps generally applicable evidence law limits that render certain forms of testimony inadmissible. Some distinguished commentators argue that courts should rebuff Sixth Amendment claims along these lines so long as the nonconstitutional evidence law rule in question applies in generally applicable fashion to limit equally the testimony-presenting prerogatives of both criminal defendants and prosecutors. See Akhil Reed Amar, Sixth Amendment First Principles, 84 GEO. L.J. 641, 699 (1996) ("If the government cannot compel a doctor to testify against his patient, because of a general doctor-patient privilege, a defendant cannot so compel this doctor."); Richard A. Nagareda, Reconceiving the Right to Present Witnesses, 97 MICH. L. REV. 1063, 1069 (1999) (arguing "that a wide array of sources . . f form a compelling case to reconceive the right [to compel witness attendance] as one of equal treatment"). The Court, however, has rejected this approach, holding instead that generally applicable evidence rules, including rules on privilege and hearsay, must sometimes give way to ensure the vindication of the defendant's constitutional rights. See IMWINKELRIED, supra, § 11.2.1; accord id. § 11.2.2. (noting that under the Court's rulings, "criminal defense counsel now have a constitutional argument for overriding exclusionary rules in the form of statutes, common law decisions, or court rules" in light of "the constitutionalization of the accused's right to present defense evidence" (citation omitted)).

Moreover, the Court's approach makes sense. After all, as a noted treatise writer explains, "many of the constitutional provisions impacting evidence are found in the Bill of Rights; and rather than implementing an equality model, the essential thrust of the Bill of Rights is to impose special restrictions on the government." Id. § 11.4.1; see id. $\$ 11.3 .2$ (adding that it is "clear that the courts ought to employ as-applied analysis in adjudicating the constitutionality of evidentiary rules attacked under the accused's constitutional right to present evidence"). The bottom line is that under governing Supreme Court doctrine, the Sixth Amendment sometimes requires departure from "purportedly absolute" common law or statutory rules of evidence law. Id. § 11.311.3.1. And if such departures are required by the Sixth Amendment, one is left to ask why they should not likewise be required by the First. 


\section{A. O'Brien and Generally Applicable Rules of Evidence}

As discussed above, some judges might seek to immunize evidence law from as-applied First Amendment attacks because of its generally applicable character. There is, however, a front-and-center problem with this line of analysis. In contrast to its approach to free-exercise cases, the Court long has refused to apply a rule of automatic validation to generally applicable laws in the Free Speech Clause context.

This story begins with United States v. O'Brien. There, the Court upheld the conviction of a draft-card-burning war protester under a law that, in generally applicable fashion, prohibited the mutilation of documents issued by the Selective Service System. ${ }^{142}$ Taking an approach fundamentally different from that in Smith, the Justices did not reject the defendant's constitutional challenge simply because the mutilation ban was generally applicable in character. Instead, the Court undertook a case-specific balancing analysis, inquiring whether the government interests offered in support of the statute qualified as "substantial" and whether there existed an adequate "less restrictive" alternative for advancing those interests. ${ }^{143}$ In short, the Court directed what it later described as an "intermediate level of scrutiny" at the speech-specific application of the statute to the defendant. ${ }^{144}$ Notably, O'Brien does not stand alone in applying this form of heightened scrutiny to generally applicable laws. In later cases-including controversial post-Smith cases involving the claimed free-speech rights of nude dancers - the Court has continued to apply this intermediatescrutiny style of review to Free Speech Clause challenges directed at generally applicable laws. ${ }^{145}$

142. United States v. O’Brien, 391 U.S. 367, 370 (1968).

143. Id. at 380-82.

144. See, e.g., Turner Broad. Sys., Inc. v. FCC, 512 U.S. 622, 661-62 (1994).

145. In Barnes v. Glen Theatre, Inc., 501 U.S. 560 (1991), for example, the Court encountered a challenge to a generally applicable ban on nudity in public places, as applied to erotic dancers who performed at nightclubs. Id. at 563. All nine Justices accepted the premise that nude dancing is protected speech. See id. at 565-66 (plurality opinion of Rehnquist, C.J.); id. at 580-81 (Scalia, J., concurring in the judgment); id. at 581 (Souter, J., concurring in the judgment); id. at 587-88 (White, J., dissenting). Having joined the Court in doing so, however, Justice Scalia went on to urge the Court to abandon the O'Brien approach in light of Smith, thus rendering the nudity ban automatically immune from First Amendment challenge because of the law's general applicability. Id. at 579-80 (Scalia, J., concurring in the judgment). See also Jed Rubenfeld, The First Amendment's Purpose, 53 STAN. L. REV. 767 (2001) (advocating the same approach). Every other member of the Court, however, employed the O'Brien methodology. See Dan T. Coenen, Free Speech and Generally Applicable Laws: A New Doctrinal Synthesis, 103 IowA L. REV. 435, 473-74 (2018). 
There is, however, more to the story because of the Court's opinion in Turner Broadcasting System, Inc. v. FCC. ${ }^{146}$ There, Justice Kennedy asserted that, under present-day doctrine, "a generally applicable law may or may not be subject to heightened scrutiny under the First Amendment." 147 In support of this seeming retreat from O'Brien, however, Justice Kennedy cited only one case, Cohen $v$. Cowles Media Co. ${ }^{148}$ In that case, the Court rejected a First Amendment challenge to a promissory-estoppel-based damages judgment entered against a reporter who had breached an agreement to keep secret a source's identity. ${ }^{149}$ Moreover, in doing so, the Court emphasized that the state promissory-estoppel law was "generally applicable" in nature. ${ }^{150}$ As Professor Eugene Volokh properly explains, however, the Court focused on the generally applicable character of promissory-estoppel law in rebuffing a Free Press Clause argument-rather than a Free Speech Clause argument-advanced by the defendant-reporter. ${ }^{151}$ In other words, the Court ruled that the general applicability of the promissory-estoppel cause of action meant that the reporter, regardless of his role as a member of the press, was entitled to no greater First Amendment protection from liability for promise-breaking than any other promise-breaking speaker. As for any separate Free Speech Clause challenge, Volokh further (and again soundly) explains that the Court's ruling was extremely narrow. ${ }^{152}$ At most, it held that the reporter, precisely because he promised not to communicate the source's identity, had voluntarily waived any Free Speech Clause right he otherwise might have been able to invoke to escape the state's restriction on speech. ${ }^{153}$

The foregoing analysis signals that O'Brien's intermediatescrutiny approach remains fully operational in cases that involve freespeech challenges to the generally applicable law of evidence because-to say the least-involuntarily becoming a criminal

146. Turner Broad. Sys., Inc. v. FCC, 512 U.S. 622 (1994)

147. Id. at 640 (emphasis added).

148. Cohen v. Cowles Media Co., 501 U.S. 663 (1991) (cited in Turner Broad. Sys., Inc., 512 U.S. at 640).

149. Cohen, 501 U.S. at $665-66,672$.

150. Id. at 670 .

151. Volokh, supra note 71, at 1294-96.

152. Id. at 1297.

153. Id. For a far more detailed analysis, see Coenen, Free Speech and Generally Applicable Laws, supra note 145, at 468-73. As is concluded in that work, "a waiver theory best explains the Court's treatment of the free-speech issue in Cohen." Id. at 472. 
defendant does not bespeak a voluntary waiver of one's Free Speech Clause rights. Thus, there is good reason to conclude that the $O^{\prime} B r i e n$ test, or at least some form of $O^{\prime} B r i e n$-style scrutiny, should apply in past-speech-evidence cases. To be sure, judicial use of an $O$ 'Brien-type test in this context does not ensure that courts applying the test will conclude that it requires the exclusion of relevant past-speech evidence. Indeed, some commentators have argued that the O'Brien standard has proven so toothless in actual operation that it affords no meaningful protection to speakers in any context at all. ${ }^{154}$ This depiction, however, overstates the limitations of $O^{\prime}$ Brien-style review. The key point is that the O'Brien standard requires courts to apply a level of scrutiny described by the Court as "intermediate," and the Court has invoked intermediate scrutiny in many cases to limit the operation of speech-burdening laws. ${ }^{155}$

So, why has the Court refused to overrule its Free Speech Clause ruling in O'Brien in the wake of its subsequent Free Exercise Clause ruling in Smith? The basic reason is that judicial protection of an "uninhibited, robust, and wide-open" freedom of expression lies at the heart of our democratic system. ${ }^{156}$ And the sort of expression involved in past-speech-evidence cases puts that concern at its zenith precisely because those cases involve the burdening of speech on matters of public concern. ${ }^{157}$ For this reason, past-speech-evidence cases raise very different considerations than, say, the nude-dancing cases in which the Court found no violation of the O'Brien test.

No less important, past-speech-evidence cases present a more compelling claim for judicial intervention than even O'Brien itself in one significant respect. As others have noted, the speaker in O'Brien had many ways to communicate his message without burning his draft card-including by decrying the Vietnam War in front of the very same sympathetic crowd, while burning an exact replica of his draft card. ${ }^{158}$ In contrast, when drug-use-celebrating "trap rap" artists find

154. See, e.g., Larry A. Alexander, Trouble on Track Two: Incidental Regulations of Speech and Free Speech Theory, 44 HASTINGS L.J. 921, 945 (1993).

155. See Coenen, supra note 145 , at 474.

156. New York Times Co. v. Sullivan, 376 U.S. 254, 270 (1964); see also Coenen, Free Speech and Generally Applicable Laws, supra note 145, at 466-67 (developing this idea).

157. See supra notes 73-91 and accompanying text. Another distinction arises out of the special concern-prominently reflected in the Court's jurisprudence concerning the religion clauses-about ensuring that government institutions take a neutral view of religious institutions and practices. See, e.g., Wallace v. Jaffree, 472 U.S. 38, 60 (1985); see also Coenen, Free Speech and Generally Applicable Laws, supra note 145, at 466 (developing this distinction).

158. See, e.g., LAURENCE H. TRIBE, AMERICAN CONSTITUTIONAL LAW 983 (2d ed. 1988). 
themselves pressured to water down song lyrics, something more problematic is occurring. This is the case because any such watering down involves altering the words of their songs and thus the content of their intended messages. Indeed, such an alteration might even cause the substituted lyrics no longer qualify as trap rap at all.

In sum, notwithstanding the Court's hands-off free-exercise ruling in Smith, the hands-on, free-speech-protective ruling in O'Brien remains good law, and it is applicable in the context of past-speech evidence in a particularly powerful way. As is discussed below, a form of judicial scrutiny even stricter than the one recognized in O'Brien might well properly apply to prosecutorial use of criminal defendants' past-speech evidence. At a minimum, however, O'Brien signals that the operation of evidence rules should have to survive a meaningful form of judicial review, notwithstanding their generally applicable character, when the Government seeks to use those rules to introduce past-speech proof against criminal defendants.

\section{B. Past-Speech Evidence and Direct-in-Effect Burdens on Expression}

Another line of Free Speech Clause authority confirms that judges should thoughtfully police prosecutorial use of past-speech evidence, whether or not it is relevant. This doctrine teaches that a generally applicable law requires especially "demanding" scrutiny ${ }^{159}$ when its application imposes not just an O'Brien-type "incidental" burden on speech, but a burden that qualifies as direct in effect. ${ }^{160}$

This point is illustrated by Holder v. Humanitarian Law Project, ${ }^{161}$ which involved an as-applied Free Speech Clause challenge to a federal statute that prohibited the provision of "material support" to any government-listed terrorist group. ${ }^{162}$ Following this statute's enactment, a nonprofit organization sued to block the law's operation to the extent that it precluded the organization from training a terrorist group's members about peaceably pursuing the group's underlying aims. ${ }^{163}$ According to the organization, this application of the law violated the First Amendment because the training the organization sought to engage in plainly involved protected speech. ${ }^{164}$ The

159. See infra note 172 and accompanying text.

160. The phrase "direct in effect" is my own.

161. Holder v. Humanitarian Law Project, 561 U.S. 1 (2010).

162. Id. at $7-8$.

163. Id. at $10-11$.

164. Id. at 10,14 . 
Government's counterargument centered on the claim that the statute was subject to, and satisfied, the O'Brien test. ${ }^{165}$ In its view, the material-support law qualified as generally applicable because most of its applications - for example, to defendants charged with transferring weapons or cash to terrorists - did not involve training or other forms of expression. ${ }^{166}$ Thus, according to the Government, the applicable legal standard was O'Brien's speech-control-friendly intermediatescrutiny test.

The Court, however, concluded that Humanitarian Law Project differed from O'Brien in a key respect. ${ }^{167}$ As the Court observed, the speech of the draft-card burner in O'Brien had nothing to do with establishing the elements of the charged crime. ${ }^{168}$ Put another way, conduct in the form of draft-card mutilation was criminalized, for one and for all, entirely apart from anyone's engagement in that conduct as expression. ${ }^{169}$ In Humanitarian Law Project, however, free-speech values were threatened to a greater extent because it was the nonprofit's planned expressive activity itself-that is, its communication of information through the expressive activity of teaching - that gave rise to the very "material support" that the statute banned in its application to the case. ${ }^{170}$ Thus, the Court concluded, the material-support statute imposed a direct-in-effect, not just incidental, burden on this particular would-be speaker. ${ }^{171}$ This conclusion, in turn, led the Court to apply a mode of review to the as-applied challenge that was "more demanding" than the intermediate-scrutiny approach of O'Brien. ${ }^{172}$ In the end, the Court in Humanitarian Law Project upheld the challenged statute - hardly a surprising result because the justification underlying the statute focused on the distinctly powerful government interest of thwarting international terrorism. The key point here, however, is that the Court was crystal clear in holding that

165. Id. at 26 .

166. Id.

167. Id. at 27 .

168. United States v. O’Brien, 391 U.S. 367, 381-82 (1968) (cited in Humanitarian Law Project, 561 U.S. at 26-27).

169. O'Brien, 391 U.S. at 381-82.

170. Humanitarian Law Project, 561 U.S. at 27-28.

171. See id. at 4 (reasoning that "the conduct triggering coverage under the statute consist[ed] of communicating a message").

172. Id. at 27-28. Notably, this approach was far from unprecedented. In Humanitarian Law Project itself, the Court relied on earlier cases involving close scrutiny of breach-of-the-peace statutes as applied to protected speech. See id. (discussing Cohen v. California, 403 U.S. 15 (1971)). 
the type of as-applied challenge raised in such cases requires a much stricter form of judicial scrutiny than was operative in O'Brien.

Thus, a critical question arises: When courts apply the rules of evidence to allow a defendant's past profession of radical political beliefs or the like to be presented to the jury, are those rules operating more like the draft-card-burning law at issue in O'Brien or more like the material-support statute at issue in Humanitarian Law Project? The answer is that evidence rules are operating more like the materialsupport statute. After all, just as in Humanitarian Law Project, the Government in past-speech-evidence cases seeks to use against defendants the expressive characteristics of their past speech. In other words, the speaker-disadvantaging impact generated by the problematic evidence arises precisely because of-and not, as in O'Brien, in spite of - the fact that the defendant's actions involve communicating particular information or ideas to others. Thus, when the Government uses past-speech evidence against a defendantdeclarant, it is doing so specifically because of "the content ... of the message conveyed," 173 in the critical sense that "the content of the message" is precisely what gives the message probative power for the prosecutor's case. The burden placed on speakers through the evidentiary use of their past speech is therefore far different-because it is far more direct - than the burden placed on the speaker in O'Brien. It thus seems fair to conclude that past-speech-evidence cases call for an even-more-than-intermediate-scrutiny mode of constitutional review, in keeping with the logic of Humanitarian Law Project.

\section{Past-Speech Evidence and Sherbert}

Both O'Brien and Humanitarian Law Project show that limits on the ability to challenge generally applicable laws on constitutional grounds do not apply to Free Speech Clause cases. But even if Smith were taken to immunize generally applicable laws from free-exercise and free-speech challenges, the Smith Court itself recognized an important exception to the rule of immunity it established. This exception emanated from the Court's earlier free-exercise ruling in Sherbert $v$. Verner. And, as the following discussion indicates, the policy concerns that drove the Smith Court to recognize the Sherbert exception apply with great force in the past-speech-evidence context considered in this Article.

173. Snyder v. Phelps, 562 U.S. 443, 457 (2011). 
Sherbert arose out of a sincere Sabbatarian's free-exercise challenge to the state's refusal to grant her unemploymentcompensation benefits after she lost her job because she refused to work on Saturdays. ${ }^{174}$ The State argued that the case presented no freeexercise problem because refusals to work for "personal reasons," whether religious or not, precluded the award of unemployment benefits. ${ }^{175}$ In other words, the State's theory was that Ms. Sherbert could not mount a free-exercise challenge to the program's eligibility rules because of their generally applicable character.

In an opinion authored by Justice Brennan, the Court disagreed, reasoning that "any incidental burden on the free exercise of appellant's religion" must be "justified by a "compelling state interest." "176 Twenty-seven years later, the Court had the chance to overrule Sherbert in Smith. But it declined to do so. Instead, the Court concluded that its newly minted prohibition on free-exercise scrutiny of generally applicable laws did not extend to Sherbert-like cases. ${ }^{177}$ According to Justice Scalia, this exception to the Smith rule made sense because "the Sherbert test ... was developed in a context that lent itself to individualized governmental assessment of the reasons for the relevant conduct." 178 In other words, state decisionmakers had to consider, as a matter of state law, a variety of "eligibility criteria" in connection with "the particular circumstances behind an applicant's unemployment" in each individual case. ${ }^{179}$ In sum, Sherbert, as recast in Smith, establishes the principle that "where the State has in place a system of individual exemptions, it may not refuse to extend that system to cases of 'religious hardship' without compelling reason." 180

Smith's treatment of Sherbert raises an important question: Even assuming that evidence rules might otherwise be subject to Smith's line-in-the-sand limit on First Amendment challenges to generally applicable laws, does the Smith limit or the Sherbert exception to that

174. Sherbert v. Verner, 374 U.S. 398, 399-401 (1963).

175. Id. at 419 (Harlan, J., dissenting).

176. Id. at 403 (citation omitted).

177. Emp't Div., Dep't of Human Res. of Or. v. Smith, 494 U.S. 872, 884-85 (1990).

178. Id. at 884 .

179. Id.

180. Id. (citation omitted). Notably, lower courts have applied the Sherbert exception in a wide range of settings far removed from the unemployment-compensation context. See, e.g., Ward v. Polite, 667 F.3d 727, 738 (6th Cir. 2012) (applying such an exception to a university policy regarding counselor reassignments); Fraternal Order of Police Newark Lodge No. 12 v. City of Newark, 170 F.3d 359, 360 (3d Cir. 1999) (applying the exception to a police-department policy that banned beards). 
limit properly apply when defendants challenge prosecutorial use of past-speech evidence? The answer to this question hinges on the policy concerns that underlie the Court's treatment of Sherbert in Smith. And those policy concerns favor recognition of an analogous "expressive hardship" exception to otherwise generally applicable rules of evidence.

To begin with, if determinations made by the government ever "invite consideration of the particular circumstances" or "an individualized governmental assessment ... of reasons," 181 they do so in the context of judicial rulings on the admissibility of evidence. After all, each and every evidentiary ruling is uniquely based on the particular evidence offered and the overall context into which it fits. In addition, the law of evidence establishes "eligibility criteria" in a key, functional sense. For relevant evidence to be eligible for admission under the Federal Rules, for example, it must not be unduly prejudicial, must be nonprivileged, and must not be subject to exclusion as hearsay or improper character evidence.

Indeed, a straightforward logical argument is available based on the Court's declaration in Church of the Lukumi Babalu Aye, Inc. v. City of Hialeah ${ }^{182}$ building on Smith and Sherbert, that a state "may not refuse ... without compelling reason" to recognize a constitutional hardship exception "in circumstances in which individualized exemptions from a general requirement are available." 183 In the pastspeech-evidence context, a "general requirement" dictates that relevant evidence is admissible. But there exist many "individualized exemptions" to that rule that are triggered by privileges, hearsay limits, and the like. Thus, it seems to follow that courts "may not refuse" to apply a First Amendment exception to the relevance rule "without compelling reason." 184

What is more, there is a special justification for carrying over Sherbert's "individual government assessment" principle to pastspeech-evidence cases. In these cases, courts are very likely to find themselves assessing the prejudicial effect of the proffered speech evidence in any event. In our bombing hypothetical, for example, the defendant almost certainly would lodge an objection based on "unfair prejudice" pursuant to Federal Rule of Evidence 403 (or its state-law

181. Smith, 494 U.S. at 884 .

182. Church of the Lukumi Babalu Aye, Inc. v. City of Hialeah, 508 U.S. 520 (1993).

183. Id. at 537 (internal quotation marks and citation omitted).

184. Id. (citation omitted). 
counterpart), so that the trial court would have to assess the risk of such prejudice under background principles of evidence law. ${ }^{185}$ Against this backdrop, and in light of the Sherbert exception, it seems especially improper to preclude consideration of constitutional prejudice as part of the court's admissibility assessment. After all, when judges are already considering the prejudicial effects of proffered evidence, it hardly seems too meddlesome to call on them to take account-just as the Court did in Sherbert-of the specialized First Amendment considerations at work in the case. And this conclusion seems all the more sound in light of the judicial branch's longstanding role-and resulting specialized competence - in standing above the political fray to safeguard free-speech values.

As with O'Brien and Humanitarian Law Project, there may be reasons to conclude that the principle of Sherbert does not obviously control prosecutorial attempts to use past-speech evidence. But the policy-based thematic drift of Sherbert as refined in Smith-that it is proper to include constitutional considerations in decision-making processes focused on "particular circumstances"-bears directly on the set of problems addressed in this Article. The policy of Sherbert supports the conclusion that courts should engage with-rather than ignore-Free Speech Clause values as they make "individualized governmental assessment[s]" in evaluating objections to past-speech evidence.

\section{Past-Speech Evidence and First Amendment Due Process}

The preceding discussion reveals that the policies underlying the Court's work with generally applicable laws -including its decisions in O'Brien, Humanitarian Law Project, Sherbert, and even Smithsupport the imposition of meaningful First Amendment limits on prosecutorial use of past-speech evidence. Some analysts, however, might try to push these cases to one side by claiming that substantive legal restrictions and procedural rules of evidence necessarily fall into separate juridical categories. This view of things is dubious from the start because "thoughtful legal observers have recognized that there is no bright line between procedure and substance in whatever legal context one encounters the dichotomy." "186 But even if one embraces such a distinction with all-out enthusiasm, there is a powerful reason

185. FED. R. EVID. 403.

186. Stephen B. Burbank, Aggregation on the Couch: The Strategic Uses of Ambiguity and Hypocrisy, 106 COLUM. L. REV. 1924, 1926-27 (2006). 
not to exempt evidence law from Free Speech Clause challenges based on that law's generally applicable character. The reason stems from another set of constitutional limits-focused squarely on procedural, rather than substantive, law-that rein in the operation of many generally applicable rules. These limits center on what Professor Henry P. Monaghan famously calls "First Amendment due process." 187 As the label suggests, this doctrine draws simultaneously on substancecentered free-speech values and non-substance-centered procedural due process values. ${ }^{188}$

Consider New York Times v. Sullivan. ${ }^{189}$ In that case, the Court held that speech about public officials cannot support a defamation action unless the defendant acts with "actual malice." ${ }^{190}$ But the Court did not stop there. It also held that the burden of proof as to actual malice must rest on public-official plaintiffs and that those plaintiffs must prove such malice with "convincing clarity." 191 Obviously, state laws that provide for a preponderance-of-the-evidence standard of proof are generally applicable in nature. After all, that standard applies routinely in tort actions-indeed, in almost all civil actions of any kind. ${ }^{192}$ The Court in Sullivan, however, threw the preponderance-ofthe-evidence standard out the window. Relying on the First

187. See generally Henry P. Monaghan, First Amendment "Due Process," 83 HARV. L. REV. 518 (1970) (discussing procedural safeguards intended to limit the harm of governmental action that impedes First Amendment rights).

188. As a result, the doctrine of First Amendment due process may get a lift from an aspect of Smith that is entirely separate from the Smith Court's treatment of Sherbert. In particular, the Court recognized that its approach of insulating generally applicable laws from constitutional challenges should sometimes give way in cases that involve the "hybrid" operation of two separate constitutional protections. Smith, 494 U.S. at 881-82. This line of analysis seems fully applicable here because constitutional limits based on First Amendment due process, by their nature, stem from a hybrid right rooted in the joint operation of the First Amendment Free Speech Clause and the Due Process Clauses of the Fifth and Fourteenth Amendments. To be sure, some scholars might challenge judicial recognition of hybrid rights on textualist grounds. In particular, they might claim that such hybridization is inconsistent with the Constitution's textual structure of setting forth what seem to be separate, freestanding safeguards of individual rights. In the context of past-speech evidence, however, this textualist critique has little force. In Roaden v. Kentucky, 413 U.S. 496 (1973), the Court, in applying the Fourth Amendment, declared that "we examine what is 'unreasonable' in the light of the values of freedom of expression." Id. at 504. It seems no less appropriate to say courts should likewise look at those same "values of freedom of expression" in determining what process is "due" as they evaluate the adequacy of governmentspecified procedural rules, including the rules of evidence. See id.

189. New York Times Co. v. Sullivan, 376 U.S. 254 (1964).

190. Id. at 279-80.

191. Id. at $285-86$.

192. See 21B Charles Alan Wright \& Kenneth W. Graham, Jr., Federal Practice AND PROCEDURE $§ 5122$, at 399 (2d ed. 2005). 
Amendment, the Court compelled states to depart from this generally applicable procedural rule to ensure that free-expression values receive the level of protection that the Constitution requires. ${ }^{193}$

One might say that Sullivan sheds little light on the subject of pastspeech evidence because that case concerned only the distinctly speech-centered subject of defamation law. This reasoning is faulty, however, because the Court has invoked the Free Speech Clause to require departures from generally applicable rules of procedure in a broad array of rulings, ${ }^{194}$ including many rulings that have nothing to do with the law of defamation. ${ }^{195}$ In cases of particular relevance here, for example, the Court has wielded the tool of First Amendment due process to require appellate tribunals to review trial court findings de novo, regardless of the review standard put in place by generally applicable procedural rules. ${ }^{196}$ In light of these authorities, it is not

193. See Sullivan, 376 U.S. at 285-86 (noting that "the constitutional standard demands" imposition of the "convincing clarity" formulation).

194. See Waters v. Churchill, 511 U.S. 661, 669 (1994) (plurality opinion) (noting that "we have often held some procedures ... to be constitutionally required in proceedings that may penalize protected speech" (citations omitted)); Faulkner, supra note 5, at 13, 21 (noting that First Amendment due process applies in "numerous areas"); see also Carroll v. President \& Comm'rs of Princess Anne, 393 U.S. 175, 180 (1968) (imposing more exacting rules than otherwise would apply regarding the issuance of temporary restraining orders when they target parades or similar free-speech activities); Freedman v. Maryland, 380 U.S. 51, 57-60 (1965) (holding that a filmlicensing system avoids "constitutional infirmity only if it takes place under procedural safeguards designed to obviate the dangers of a censorship system," including by ensuring expedited judicial review); Stanford v. Texas, 379 U.S. 476, 485 (1965) (requiring heightened particularity in warrants when the materials to be seized are speech related); Bantam Books, Inc. v. Sullivan, 372 U.S. 58, 66 (1963) (requiring special procedural rules regarding state control of obscenity); Marcus v. 104 E. Tenth St., 367 U.S. 717, 731-33 (1961) (imposing special requirements for warrants regarding seizures of speech-related materials). In the same vein are rulings that apply First Amendment overbreadth doctrine, which alters traditional jurisdictional rules of standing. See generally Richard H. Fallon, Jr., Making Sense of Overbreadth, 100 YALE L.J. 853 (1991) (discussing various ways the judicial system has dealt with statutes that are overly broad in the conduct they regulate).

195. See Mt. Healthy City Sch. Dist. Bd. of Educ. v. Doyle, 429 U.S. 274, 287 (1977) (adopting burden-of-proof-shifting methodology to deal with mixed-motive speech cases); Speiser v. Randall, 357 U.S. 513, 526 (1958) (imposing the burden of proof on the Government when dissident taxpayer-speakers were denied tax exemptions); see also Noto v. United States, 367 U.S. 290, 299-300 (1961) (requiring judicial assessment of proof of a defendant's membership in an organization "strictissimi juris" to ensure that the defendant is not "punished for his adherence to [that organization's] lawful and constitutionally protected purposes because of [the organization's] other and unprotected purposes which he does not necessarily share"); Scales v. United States, 367 U.S. 203, 229 (1961) (requiring “clear proof” of the defendant's specific intent not just to join a revolutionary organization but also to accomplish its unlawful aims).

196. See Bose Corp. v. Consumers Union of U.S., Inc., 466 U.S. 485, 514 (1984) (requiring use of de novo review "in reviewing a determination of actual malice"); Yates v. United States, 354 U.S. 298, 328 (1957) (endorsing "rigorous standards of review" in incitement-related Smith Act 
surprising that other analysts - including Professor Quint - focus their attention on First Amendment due process principles in urging courts to place free-expression-based limits on prosecutorial use of pastspeech evidence. ${ }^{197}$

There is much merit in this approach. But analysts who have relied on it have failed to note that there is an analytical fly in the ointment. The problem is that it is one thing to say that courts can override generally applicable procedural rules, but it is a very different thing to say that courts must do so-or even that they must think hard about doing so. ${ }^{198}$ This point takes on a sharper focus when one recalls that the principle of First Amendment due process differs in a significant way from the principles laid down in O'Brien, Humanitarian Law Project, and Sherbert. If a challenged government action falls within the reach of those three precedents, after all, it automatically triggers specialized scrutiny; indeed, if either Humanitarian Law Project or Sherbert applies with full force, the challenged government action is subject to the strictest form of constitutional review.

The law of First Amendment due process, however, operates differently because there are large numbers of generally applicable procedural rules that apply equally (and noncontroversially) in both free-speech-related and other cases. Courts, for example, have never professed to apply intermediate or strict scrutiny - or, indeed, any level of First Amendment scrutiny at all-to civil pleading requirements, jury selection procedures, the requisite level of jury consensus, indictment-specificity rules, or the probable-cause charging requirement, even when the case centers on speech-related activity. The key point is that many procedural rules have never been understood to trigger elevated as-applied Free Speech Clause review. Put another way, if a First Amendment overlay on generally applicable rules of evidence were to find its moorings in authorities such as Sullivan, that overlay would require a special singling out of the law of evidence because the Court's past rulings have created only a here-

prosecutions).

197. Quint, supra note 2, at 1641; accord Faulkner, supra note 5, at 13 (noting that "because First Amendment rights are particularly susceptible to infringement, the Court has been willing to adopt extraordinary procedural safeguards" in an effort to safeguard those rights).

198. Professor Quint, for example, seems to gloss over this point when he claims, without qualification, that "procedural guarantees must be applied with special strictness when First Amendment rights are at stake." See Quint, supra note 2, at 1641. 
and-there, exceptional-situation, hodge-podge set of First Amendment due process limits. ${ }^{199}$

This is not to say that there is no basis for recognizing a First Amendment due process limit on generally applicable evidence law. Far from it. ${ }^{200}$ It $i s$ to say, however, that proponents of this approach must justify Free Speech Clause policing of the generally applicable rules of evidence with an argument that reaches beyond simply uttering the mantra of "First Amendment due process." Is that possible? Many past rulings of the Court signal that it is. Most notably:

1. Under the Noerr-Pennington doctrine, courts must exempt from the general application of antitrust statutes collective efforts by otherwise competing businesses to secure jointly self-serving changes in the law. ${ }^{201}$ In Footnote 3 of United Mine Workers v. Pennington, ${ }^{202}$ the Court noted that this principle would not necessarily preclude the use of evidence of such collective efforts as part of an effort to prove the defendant's engagement in more nefarious forms of collusion, such as price-fixing. ${ }^{203}$ But the Court also observed that it would "be within the province of the trial judge to admit this evidence, if he deemed it probative and not unduly prejudicial." ${ }^{204}$ This passage thus supports the imposition of a prejudice-based First Amendment limit on use of pastspeech evidence, even if the evidence is deemed relevant. ${ }^{205}$

2. In Abrams v. United States, ${ }^{206}$ the Court upheld the convictions of five defendants under the Espionage Act for disseminating pamphlets containing "disloyal, scurrilous and abusive" statements

199. Waters, 511 U.S. at 670-71 (plurality opinion) (noting that "not every procedure that may safeguard protected speech is constitutionally mandated"; that "[w]e have never set forth a general test to determine when a procedural safeguard is required"; that only "some procedural requirements" are mandated by the First Amendment; and that "[n]one of us have discovered a general principle to determine where this line is to be drawn").

200. Professor Quint, for example, argues that the Sullivan burden-of-proof rule supports "a stringent rule of exclusion" in past-speech-evidence cases because of the "more compelling" individual interests at stake in criminal, as opposed to civil, proceedings. Quint, supra note 2, at $1660 \&$ n. 132 .

201. See, e.g., Faulkner, supra note 5, at 29-30 (citations omitted).

202. United Mine Workers of Am. v. Pennington, 381 U.S. 657 (1965).

203. Id. at 670 n.3.

204. Id. (emphasis added).

205. See Feminist Women's Health Ctr., Inc. v. Mohammad, 586 F.2d 530, 543 n.7 (5th Cir. 1978) (deeming evidence properly excluded based on "prejudice" concerns under Footnote 3 , given "the defendants' [F]irst [A]mendment interests").

206. Abrams v. United States, 250 U.S. 616 (1919). 
about the nation's involvement in World War I. ${ }^{207}$ The case, however, has since come to stand for the libertarian views expressed in the "classic" opinion of the great dissenter, Justice Holmes. ${ }^{208}$ Holmes's analysis focused on the idea that the defendants' words did not rise to the level of proscribable incitement. ${ }^{209}$ In a little-noticed sentence regarding the defendants' past statements, however, Justice Holmes also asserted that "no one has a right even to consider [them] in dealing with the charges before the Court." 210 And a principle under which "no one has a right even to consider" a defendant's past protected speech signals that, at least in some cases, such speech may not be used as evidence.

3. Gibson v. Florida Legislative Investigation Committee ${ }^{211}$ arose out of a legislative committee's effort to require the presentation of evidence-namely, an official listing of a local NAACP branch's members - in connection with an investigation of ties between that organization and the Communist Party. ${ }^{212}$ After an NAACP official refused to supply this material, he was held in contempt. ${ }^{213}$ The Court, however, overturned the imposition of this penalty, stating that "it is an essential prerequisite to the validity of an investigation which intrudes into the area of constitutionally protected rights of speech, press, association and petition that the State convincingly show a substantial relation between the information sought and a subject of overriding and compelling state interest." ${ }^{114}$ The Court went on to declare that "the Committee has not 'demonstrated so cogent an interest in obtaining and making public' the membership information . . . as to 'justify the [threatened] substantial abridgment of associational freedom.'" 215 Plainly, judicial proceedings, no less than legislative proceedings, can "intrude[] into the area of constitutional rights" - indeed, intrude so greatly that they deprive the defendant of life or liberty. And so, it is hard to see why similar prosecutorial efforts

207. Id. at 617 (internal quotation marks omitted).

208. Vincent Blasi, The Pathological Perspective and the First Amendment, 85 COLUM. L. REV. 449, 469 n.51 (1985).

209. Abrams, 250 U.S. at 628 (Holmes, J., dissenting).

210. Id. at 630 .

211. Gibson v. Fla. Legislative Investigation Comm., 372 U.S. 539 (1963).

212. Id. at 540-42.

213. Id. at 543 .

214. Id. at 546.

215. Id. (citation omitted). 
to elicit evidence of public-concern speech should not be subject to the same sort of speech-sensitive judicial balancing that the Court endorsed in Gibson. ${ }^{216}$

4. As Professor Quint details, the Court has invoked First Amendment due process principles to install specialized constitutional rules in free-speech cases, not only as to the required quantum of evidence, as in Sullivan, but also as to the minimum sufficiency of evidence. ${ }^{217}$ Although these rulings technically do not concern the admissibility of evidence, they operate to strip evidence of the probative effect it otherwise would have. ${ }^{218}$ As common sense suggests, rules that deprive evidence of probative significance are little different, as a practical matter, from rules that exclude evidence from consideration by the factfinder. Accordingly, the recognition of First Amendment due process limits in the former context lends support to the recognition of similar limits in the latter.

5. In Branzburg v. Hayes, ${ }^{219}$ Justice Powell-in supplying the decisive fifth vote in support of the majority's ruling - endorsed a First Amendment balancing rule designed to override the generally applicable principle that permits grand juries to require the presentation of all relevant evidence. ${ }^{220}$ More specifically, he concluded

216. See Quint, supra note 2, at 1663 n.142 (detailing why, because of what is at stake in each, "the First Amendment interest is, if anything stronger" when past-speech evidence is offered in criminal proceedings than in legislative proceedings); see also Anderson, supra note 5, at 933 (emphasizing the particularly "great" speech-burdening effect when challenged evidence "may be responsible for a conviction").

217. See, e.g., Quint, supra note 2, at 1654 (discussing the Noto and Scales cases and the "unusually rigorous" proof requirements they impose for demonstrating constitutionally required specific-intent requirements); see also Virginia v. Black, 538 U.S. 343, 366 (2003) (rejecting an evidentiary presumption that drew an inference of intent to intimidate from expressive action standing alone). Notably, lower courts have built on these precedents in speech-protective ways. See Quint, supra note 2, at 1656 (discussing the First Circuit's Spock case as displacing generally applicable "restrictions on the sufficiency of the evidence to impose special First Amendment limitations"); id. at 1654-55 (reflecting similarly on the Ninth Circuit's Hellman decision).

218. In particular, these cases suggest that, absent free-speech concerns, level of evidence A would be sufficient to convict, but that because the Free Speech Clause is in the picture, a higher level of evidence-say, A plus B-is required. The practical effect of such a rule is to render ineffectual any body of evidence less than A plus B. In particular, evidence A standing aloneeven if it is so probative that it would take the case to the jury under ordinary circumstances - is deemed to have no probative effect at all, entirely because of the force exerted by the First Amendment.

219. Branzburg v. Hayes, 408 U.S. 665 (1972).

220. See Sonja R. West, Concurring in Part \& Concurring in the Confusion, 104 MICH. L. REV. 1951, 1951, 1954 (2006) (arguing that Justice Powell's endorsement of a balancing test embodies 
that when significant free-speech concerns present themselves-as when a reporter seeks to avoid disclosing the name of a confidential source - the judge must "strik[e] ... a proper balance between freedom of the press and the obligation of all citizens to give relevant testimony ... on a case-by-case basis." ${ }^{221}$ Again, the analogy to cases involving prosecutorial use of past-speech evidence is apparent. If the Government must run the gauntlet of a speech-protective balancing test when it seeks to compel the presentation of relevant evidence merely to a grand jury, simple logic suggests that it should have to do no less when it seeks to compel the presentation of such evidence in the criminal trial itself. ${ }^{222}$

6. Finally, the Court's ruling in Dawson supports the endorsement of a meaningful judicial role in policing evidentiary use of publicconcern speech. To be sure, the focal point of the Court's reasoning in Dawson was that the challenged evidence lacked relevance to the issues under consideration by the jury. On the better view, however, the Court required something more than ordinary evidentiary relevance, ${ }^{223}$ while also emphasizing the prejudicial nature of the challenged Aryan Brotherhood proof, which focused on the defendant's "morally reprehensible" beliefs. ${ }^{224}$ In any event, judicial endorsement of a constitutional rule that ties exclusion of past-speech evidence solely to a finding of relevance makes little, if any, sense as a matter of First Amendment policy. It is, after all, the presence of a prejudicial impact on the exercise of free-speech rights - and not the problem of evidentiary irrelevance-that gives rise to a First Amendment problem in past-speech-evidence cases in the first place. ${ }^{225}$

the holding in Branzburg because he supplied the critical fifth vote).

221. Branzburg, 408 U.S. at 710 (Powell, J., concurring). See also Nickerson, supra note 6, at 846 (noting that "most appellate circuits have adopted the case-by-case approach" of Justice Powell).

222. See Quint, supra note 2, at 1664 (noting that "the First Amendment interests favoring exclusion of a defendant's protected speech at trial seem substantially stronger than the interests favoring exclusion of similar material from consideration by the grand jury" because of the prospect of actual conviction at trial).

223. See Faulkner, supra note 5, at 42 (arguing that Dawson required that "evidence must be really relevant to be admitted over a First Amendment objection" and that "the conclusion of irrelevance in Dawson was a fiction"); id. at $40 \mathrm{n} .233$ (describing Dawson as involving "supranormal relevance scrutiny"); Nickerson, supra note 6, at 859 n.76 (same).

224. Dawson v. Delaware, 503 U.S. 159, 167 (1992); see Faulkner, supra note 5, at 38 (noting that while Dawson "ostensibly rested on relevance grounds, its holding of 'constitutional error' can only be explained in terms of prejudice").

225. See supra notes 58, 107-09 and accompanying text. 
In addition, a relevance-only approach to admissibility would invite odd and troubling results. In particular, such an approach might well foreclose the use of irrelevant past-speech proof that presents only limited dangers of free-expression-related prejudice, while allowing the use of only marginally relevant evidence even when it presents the most far-reaching dangers of free-expression-related prejudice. Simply put, it is strange-if not anomalous-to reject the weighing of evidentiary prejudice in this First Amendment context when it is that very prejudice that alone brings the First Amendment into play. ${ }^{226}$

At the very least, Dawson swept away a key argument against recognition of First Amendment limits on past-speech evidencenamely, the argument that any particular application of the rules of evidence is rightly exempt from challenge under the Free Speech Clause because of those rules' generally applicable nature. This is the case because the Delaware courts had concluded - with good reasonthat the Aryan Brotherhood proof that the Supreme Court deemed inadmissible under the Free Speech Clause was relevant under the generally applicable rules of state evidence law. ${ }^{227}$ Accordingly, with Dawson, the horse is out of the barn. There no longer can be doubt that there exist some First Amendment limits on otherwise operative general rules of evidence law. Thus, courts must recognize and define those limits, and they must do so with underlying First Amendment policies in mind.

\section{E. Potential Counterarguments}

The foregoing discussion supports three conclusions. First, arguments for broadly rejecting constitutional challenges to the admission of past-speech evidence based on cases such as Haupt, Dawson, and Mitchell, or based on the general applicability of rules of evidence, are not sustainable. Second, constitutional precedent and policy-including with regard to the proper evaluation of generally applicable laws-support recognition of a meaningful judicial role in policing the use of past-speech evidence. Third, any such meaningful assessment must thoughtfully take into account not only the relevance of proffered past-speech evidence, but also its potential prejudicial effects.

226. See Faulkner, supra note 5, at 9 (finding "reason to suppose that a majority [in Dawson] would embrace a balancing approach which would flexibly protect First Amendment values").

227. See supra note 52 and accompanying text. 
Others may well look to find missteps in this line of analysis. They might claim, in particular, that the argument misuses precedent, wrongly minimizes vital government interests, invites undue uncertainty, or ignores key features of free-expression theory. This Section addresses each of these potential critiques.

1. Precedent. As to precedent, skeptics might argue that the authority-based arguments set forth above seek to place square pegs in round holes. On this view, the question presented by prosecutorial use of past-speech evidence is far removed from the questions dealt with in O'Brien, Humanitarian Law Project, and Sherbert because those cases involved substantive legal restrictions, not "just" the use of speech as part of the Government's effort to prove the defendant's guilt. ${ }^{228}$ These critics might add that the Court in those cases subjected challenged laws to traditional forms of means-ends analysis that are not well suited for use by courts as they go about making contextual judgments about the admissibility of evidence. ${ }^{229}$ To say that neither O'Brien nor Humanitarian Law Project nor Sherbert is directly controlling in past-speech-evidence cases, however, is to miss the key point-namely, that the analytical grounding of each of these precedents suggests that courts must do more than pay mere lip service to free-speech values in this context. And this takeaway gains still more strength when one considers these precedents as a collective whole, together with the Court's highly libertarian jurisprudence regarding speech on matters of public concern. In sum, the gravitational pull of the Court's existing Free Speech Clause jurisprudence is powerful in this context, and it suggests that courts must assess in a meaningful way First Amendment objections to prosecutorial use of past-speech evidence.

2. Policy. Skeptics might also make arguments of policy. They could assert, for example, that admitting past-speech evidence at trial is important because it is probative, often on matters that are otherwise

228. See supra note 71 and accompanying text.

229. Complexity rears its head, in part, because judges cannot vindicate First Amendment values in the context of past-speech evidence in one fell swoop. They cannot, for example, craft the sort of bright-line solution used in Sherbert, where the Court announced that all sincere Sabbatarians simply cannot be, on that basis, excluded from receiving workers-compensation benefits. See supra notes 174-80 and accompanying text (discussing Sherbert). But that hardly means that courts cannot deal with First Amendment evidence problems just as they deal with other objections to concededly relevant evidence - that is, by taking account of both evidentiary relevance and competing values. 
difficult to prove, such as the defendant's state of mind. These skeptics might add that judges, if given the chance, would afford too much weight to free-speech-related "prejudice," thus frustrating the state's vital interest in securing proper criminal convictions. These points, however, are overdrawn. Any proper judicial assessment of pastspeech evidence necessarily would involve judicial consideration not only of potential prejudicial effects, but also of the probative value of the evidence and of prosecutorial needs, with the consequence that much, if not most, past-speech evidence would be admitted. Judges are trusted in other contexts to apply evidence rules in a fair-minded fashion. There is, accordingly, no sound reason to conclude that these same judges would suddenly fall into a misplaced mindset that fixates myopically on the risk of prejudicial effects when asked to apply constitutional limits to the use of past-speech evidence.

3. Predictability. Critics might advance another objectionnamely, that the contextual weighing of the costs and benefits of pastspeech evidence, under some inevitably fuzzy First Amendment rule, would unduly complicate evidence law and add a new layer of complexity to the already-challenging adjudication of criminal cases. The premise of this argument is shaky. For example, as previously noted, federal courts already must engage in the trial-complicating balancing of probative value and unfair prejudice when they apply Federal Rule of Evidence 403 to all sorts of evidence. Enriching this analysis to take special account of free-speech concerns - and doing so only in the discrete set of cases involving speech on matters of public concern-thus does not seem to be a game-changer in terms of administrative tribulations. There is a deeper point, too. Time and again, the Court has indicated that when vital constitutional interests are at stake, concerns about "administrative convenience" must give way. ${ }^{230}$ Even more fundamentally, the great mass of constitutional law supports a basic proposition of overarching salience here - the goal of protecting core constitutional rights is not to be sacrificed on an altar built of easy-to-apply rules. ${ }^{231}$

230. See, e.g., Riley v. Nat'l Fed'n of the Blind of N.C., Inc., 487 U.S. 781, 795 (1988) (noting that "the First Amendment does not permit the State to sacrifice speech for efficiency"); Carey v. Population Servs. Int'l, 431 U.S. 678, 691 (1977) (“[T]he prospect of additional administrative inconvenience has not been thought to justify invasion of fundamental constitutional rights."); Craig v. Boren, 429 U.S. 190, 198 (1976) (rejecting "administrative ease and convenience as sufficiently important objectives to justify gender-based classifications").

231. See, e.g., Cty. of Allegheny v. ACLU, 492 U.S. 573, 606 (1989) ("It is perhaps 
Indeed, in a seminal public-concern-speech case, Connick v. Myers, ${ }^{232}$ the Court emphatically endorsed a context-specific-and frustratingly tough-to-administer-balancing approach. There, the Court confronted the question whether a terminated public employee can succeed on a First Amendment claim when the firing allegedly resulted in part from her engagement in public-concern speech. ${ }^{233}$ The Court declared that deciding such a case requires an analysis that includes "full consideration of the government's interest," 234 as well as the precise "nature of the employee's expression" 235 and "the context" in which the government decided to act. ${ }^{236}$ Also significant is whether the speech "touched upon matters of public concern in only a most limited sense" 237 or involved such matters "more substantially." ${ }^{238}$ The Court acknowledged that "such particularized balancing is difficult,"239 but it also insisted that a more wooden approach was unacceptable in light of "the enormous variety of fact situations" that such cases present. $^{240}$ As with public-concern speech in the public-employee context, so too with public-concern speech that the Government seeks to use as evidence. In both settings, judges can and "must reach the most appropriate possible balance of the competing interests" ${ }^{\prime 241}$ after taking account of "the whole record." 242

\footnotetext{
unfortunate, but nonetheless inevitable, that the broad language of many clauses within the Bill of Rights must be translated into adjudicatory principles that realize their full meaning only after their application to a series of concrete cases.").

232. Connick v. Myers, 461 U.S. 138 (1983).

233. Id. at $141-42$.

234. Id. at 150 .

235. Id.

236. Id. at $153-54$.

237. Id. at 154 .

238. Id. at 152 .

239. Id. at 150 .

240. Id. at 154 (quoting Pickering v. Bd. of Educ., 391 U.S. 563, 569 (1968)).

241. Id. at 150 .

242. Id. at 148. In a post-Connick ruling that again concerned speech on matters of public concern, a four-Justice plurality even more pointedly explained that while "lack of [a more particularized] test is inconvenient, . . . this does not relieve us of our responsibility to decide the case"; the result is that courts must "answer[] the question on a case-by-case basis." Waters v. Churchill, 511 U.S. 661, 671 (1994). Indeed, there are special reasons to say that courts should carry over a Connick-like balancing approach to past-speech-evidence cases. First, public employees choose to be public employees - and thus to assume the speech-related limits that attend that role. Criminal defendants, in contrast, do not choose to be criminal defendants. Second, in endorsing judicial balancing in cases such as Connick, the Justices have emphasized the difference between government action as an "employer" (with concomitantly greater authority to manage speech) and as a "sovereign" (with concomitantly lesser authority to manage
} 
4. Free-Speech Theory. Finally, those who favor insulating evidence law from free-speech-based attacks might seek to leverage the prior work of First Amendment theorists, most notably thenProfessor and now-Justice Elena Kagan. According to Justice Kagan's pre-appointment scholarship, free-speech doctrine should center not so much on guarding against the speech-burdening effects of government actions as on policing the government's impermissible speech-suppressive motives. ${ }^{243}$ Building on this theme, analysts might reason that the framers of the Federal Rules of Evidence and kindred bodies of state law obviously did not act with the motive of targeting unpopular speakers. It follows, so the argument goes, that the introduction of past-speech evidence merits no special judicial attention, regardless of any speech-burdening impact that evidence might produce in any particular case.

One problem with this analysis is that controversy surrounds the effort to cast free-speech law as properly centered on addressing improper government motives. Indeed, many scholars have argued that real-world effects, as opposed to government purposes, should take center stage in First Amendment analysis. ${ }^{244}$ Justice Kagan herself

speech). Id. at 671-74. Without question, when the State marshals evidence in a criminal prosecution, it is acting not as an employer, but as a sovereign. See Nickerson, supra note 6, at 885-86 (noting the special claim for case-by-case assessments when criminal subpoenas or civil discovery orders involve the surrender of evidence concerning speech on matters of public concern). Perhaps most importantly, the Court already has recognized the need to engage in a "case by case" analysis of the operation of generally applicable evidence rules to ensure the proper operation of constitutional fundamental rights. See IMWINKELRIED, supra note 141, § 11.3 (noting that the Supreme Court has taken an "ad hoc" and "case-specific" approach to determining, pursuant to a "balancing test" with an "as-applied nature," whether generally applicable rules of evidence law must give way because of the constitutional right of confrontation); Nagareda, supra note 141, at 1067-81 (describing the Court's approach in this area as requiring "case-by-case," "ad hoc," and "as applied" assessments). For illustrative cases, see Rock v. Arkansas, 483 U.S. 44, 61 (1987) (holding that because of the right of defendants to testify on their own behalf, the generally applicable state bans on hypnotically refreshed testimony must give way, so long as particular "circumstances present an argument of admissibility"), Chambers v. Mississippi, 410 U.S. 284, 302 (1973) (refusing to apply hearsay law "mechanistically," and instead requiring attentiveness to "the circumstances of the particular case"), and Roviaro v. United States, 353 U.S. 53, 62 (1957) (stating that "no fixed rule" controls the constitutional inquiry and calling instead for "balancing" based on "the particular circumstances of each case").

243. See Kagan, supra note 72, at 414 (asserting that free-speech law's "primary, though unstated, object" is "the discovery of improper governmental motives"); see also Srikanth Srinivasan, Incidental Restrictions of Speech and the First Amendment: A Motive-Based Rationalization of the Supreme Court's Jurisprudence, 12 CONST. COMMENT. 401, 418 (1995).

244. See, e.g., Michael C. Dorf, Incidental Burdens on Fundamental Rights, 109 HARV. L. REV. 1175, 1179 (1996) (advocating an effects-based approach under which "laws having the incidental effect of substantially burdening fundamental rights to engage in primary conduct should be 
acknowledged that effects-based analysis has driven some significant features of free-speech doctrine. ${ }^{245}$ And most important of all, the Court itself has pointedly declared that the "abridgement of [freeexpression] rights, even though unintended, may inevitably follow from varied forms of government actions." 246

In any event, even under a purpose-centered view of the Free Speech Clause, there is an overwhelming difficulty with opposing a rule of contextual judicial assessments of past-speech evidence. The difficulty arises because - as even Justice Kagan notes - impermissible speech-punishing motives oftentimes lie not in the enactment of laws, but in their application. ${ }^{247}$ And courts properly have devised many "prophylactic" constitutional rules to ensure that impermissible government purposes do not lead to the harming of protected speakers. ${ }^{248}$ Adopting such a protective rule in the past-speechevidence context seems especially justifiable because, as previously shown, the risk is acute that juries confronted with this evidence will latch onto it precisely (and improperly) because the defendant's statements veer away from conventional norms. ${ }^{249}$ No less important, if courts are to deal with this danger, they have no choice but to do so by employing a prophylactic, pre-admission policing mechanism. Why? Because even if juror motives were otherwise readily subject to discovery-which they are not-post-trial challenges to verdicts are precluded by settled rules that broadly prohibit the second-guessing of juror thought processes and discussions. ${ }^{250}$ In sum, a purpose-centered

subject to heightened scrutiny"); see also Kagan, supra note 72, at 413 (acknowledging that "most descriptive ... as well as most normative discussions of [First Amendment] doctrine ... focus[] on the effects of a given regulation").

245. See Kagan, supra note 72 , at 427.

246. NAACP v. Alabama ex rel. Patterson, 357 U.S. 449, 461 (1958) (emphasis added); see also Waters, 511 U.S. at 670 (plurality opinion of O'Connor, J.) ("[T]he First Amendment creates a strong presumption against punishing protected speech even inadvertently ...."); Simon \& Schuster, Inc. v. Members of N.Y. State Crime Victims Bd., 502 U.S. 105, 117 (1991) ("[O]ur cases have consistently held that '[i]llicit legislative intent is not the sine qua non of a violation of the First Amendment."” (quoting Minneapolis Star \& Tribune Co. v. Minn. Comm'r of Revenue, 460 U.S. 575, $592(1983)))$.

247. See Kagan, supra note 72 , at $457,459,462-63$.

248. Id. at 457.

249. See supra notes 101-09 and accompanying text.

250. See FED. R. EVID. 606(b)(1). Leading cases barring such inquiries include Tanner $v$. United States, 483 U.S. 107, 115-16 (1987) (precluding efforts to secure evidence that jury members consumed large quantities of alcohol, cocaine, marijuana, or some combination thereof to the point that service on the jury was "one big party") and Warger v. Shauers, 135 S. Ct. 521, 525-26 (2014) (blocking testimony about jury deliberations even when offered to show that a panel member lied during voir dire, in part because this result comported with the majority of 
conception of free-speech theory supports, rather than undermines, a constitutional requirement that trial judges engage in meaningful preadmission assessments when prosecutors offer past-speech evidence.

A foundational aspect of free-speech policy confirms the correctness of this approach. At the heart of First Amendment law lies the idea that speakers should not suffer government-imposed burdens because of the viewpoints they express. ${ }^{251}$ Yet the risk of penalizing speakers on this prohibited basis is at a high ebb in past-speechevidence cases because, as illustrated by the hypothetical bomber case, the defendant may end up being convicted precisely because of the repugnance of the viewpoint the defendant has espoused. ${ }^{252}$ In short, to the extent that First Amendment law embodies special concerns about viewpoint discrimination - which it most emphatically does ${ }^{253}$ that law also should reflect a serious concern about the use of viewpoint-expressive speech offered by prosecutors at trial.

The bottom line is that First Amendment precedent and policy suggest that courts must take a contextual approach to proposed prosecutorial use of past-speech evidence, with the goal of carefully assessing the competing concerns presented by the facts of the particular case. As courts implement this idea, they will have to lay down more particularized rules that give meaningful protection to First Amendment values. The remainder of this Article considers what those rules should be.

\section{RULES FOR EVALUATING THE USE OF PAST-SPEECH EVIDENCE}

What rules should courts recognize to ensure that free-speech rights are adequately protected in past-speech evidence cases? This

common law rulings); see also Peña-Rodriguez v. Colorado, 137 S. Ct. 855, 864-65 (2017) (summarizing rules that provide "jurors with considerable assurance that after being discharged they will not be summoned to recount their deliberations ... or annoyed by litigants seeking to challenge the verdict").

251. See Rosenberger v. Rector \& Visitors of Univ. of Va., 515 U.S. 819, 829 (1995) (describing viewpoint discrimination as "an egregious form of content discrimination"); accord, e.g., Pleasant Grove City v. Summum, 555 U.S. 460, 469 (2009) (noting that "restrictions [of speech rights] based on viewpoint are prohibited").

252. See supra note 107 and accompanying text (discussing Justice Holmes's opinion in Abrams).

253. See, e.g., Matal v. Tam, 137 S. Ct. 1744, 1762 (2017) (Alito, J., for four members of the Court); id. at 1765, 1768 (Kennedy, J., for four other members of the Court). 
Part suggests three separate rules that merit recognition: one concerning trial procedure, one concerning appellate procedure, and one concerning the substantive legal standard for testing admissibility. As to trial procedure, the key reform would mandate consideration of First Amendment objections to past-speech evidence in specialized hearings conducted outside the presence of the jury. As to appellate procedure, the courts should put in place a new standard of reviewfar more exacting than the traditional "abuse of discretion" standardfor assessing claims of trial court error in past-speech evidentiary rulings. Finally, as to the proper litmus test of admissibility, courts should take care to inquire whether the probative value of the objected-to evidence outweighs all the Free Speech Clause burdens its introduction would entail, including not only burdens of unfair prejudice, but also burdens of "fair prejudice" and chilling effects.

\section{A. Trial Procedure}

The Court has long insisted that trial judges use specialized procedural rules as they assess the admissibility of evidence that is potentially subject to exclusion pursuant to constitutional commands. In Jackson v. Denno ${ }^{254}$ for example, the Court laid down specialized process requirements for dealing with objections to the evidentiary use of confessions, including a requirement that the trial court conduct "an adequate evidentiary hearing productive of reliable results."255

Taking much the same approach, the Court should insist that trial judges deploy two mechanisms of procedural care when they confront objections to past-speech evidence. First, trial judges should process these objections in carefully conducted proceedings that occur outside the presence of the jury. ${ }^{256}$ As with confessions, the hot-button character of protected-speech evidence suggests that juries should be shielded from any whiff of it unless and until the court deems it admissible. ${ }^{257}$ In addition, the risk exists that as lawyers discuss the admissibility of such evidence, the impact of that evidence on the minds of jurors is heightened-perhaps heightened greatly-even if the trial judge in the end decides to exclude it. In short, holding hearings away

254. Jackson v. Denno, 378 U.S. 368 (1964).

255. Id. at 394 .

256. Accord Faulkner, supra note 5, at 21 (endorsing this approach); Quint, supra note 2, at 1666 (same).

257. See, e.g., United States v. Carignan, 342 U.S. 36, 38 (1951); United States v. Inman, 352 F.2d 954, 956 (4th Cir. 1965). 
from the jury would help reduce both factfinder confusion and prejudicial impact. This requirement also would steer the judicial mind in the direction of assessing past-speech evidence with the heightened measure of care it rightly deserves.

Second, trial judges should have to set forth on the record their reasons for deciding to admit or exclude the challenged evidence. ${ }^{258}$ The advantages created by taking this approach are apparent. Requiring a reasoned opinion would foster analytical discipline and discourage laxity in the decision-making process. It would remind trial judges that "indispensable"259 and "preferred"260 speech-related freedoms are at stake in the case, while also helping to facilitate wellinformed appellate review. Finally, mandating reason-giving would simply slow things down. And slowing down the making of trial court rulings on Free Speech Clause objections might well serve to counteract the tendency of judges to assume too readily-in much the same way as juries might do-that past-speech evidence should bear on the outcome of a trial simply because it has some form of relevance.

\section{B. Appellate Review}

No less than trial judges, appellate tribunals should adhere to special procedures in dealing with questions that concern past-speech evidence. In particular, appellate courts should abandon the highly deferential mode of review applicable to trial court rulings made under Federal Rule of Evidence 403. ${ }^{261}$ As explained above, the Court already has put in place rules that mandate de novo appellate review of trial court actions that endanger free-speech values ${ }^{262}$ and the Court has taken the same approach in other constitutional contexts as well. ${ }^{263}$ Of particular importance here, the Court has endorsed de novo review

258. Accord Dennis, supra note 4, at 34 (endorsing this approach); Faulkner, supra note 5, at 21 (same); Quint, supra note 2, at 1666 (same).

259. NAACP v. Alabama ex rel. Patterson, 357 U.S. 449, 461 (1958).

260. Kovacs v. Cooper, 336 U.S. 77, 88 (1949).

261. See supra notes 43-44 and accompanying text; see also United States v. Ring, 706 F.3d 460, 471-72 (D.C. Cir. 2013) (indicating that, under Rule 403 review, "appellate courts must be 'extremely wary' of second-guessing” trial court rulings (quoting Henderson v. George Wash. Univ., 449 F.3d 127, 133 (D.C. Cir. 2006))).

262. See supra note 196 and accompanying text.

263. See Lilly v. Virginia, 527 U.S. 116, 136 (1999) (plurality opinion) (declaring, in applying the Confrontation Clause, that "as with other fact-intensive, mixed questions of constitutional law ... '[i]ndependent review is necessary"” (quoting Ornelas v. United States, 517 U.S. 690, 697 (1996))). 
in public-concern-speech settings. ${ }^{264}$ Against this backdrop, it is not surprising that some scholars argue for de novo review of trial court decisions that authorize prosecutorial use of past-speech evidence in the face of First Amendment objections. ${ }^{265}$

All things considered, another approach might prove to be even better. Under it, appellate courts would not engage in full-scale de novo review, but they still would steer clear, by a wide margin, of employing the traditional abuse-of-discretion standard. This style of review might be captured in terms such as "extremely confined" or "short-leash" deference. Such an approach would give trial courts some wiggle room to authorize prosecutorial use of past-speech evidence, free from all-out de novo second-guessing. ${ }^{266}$ And in doing so, short-leash deference might generate positive results for two reasons. First, it would reduce the risk of overdeterring the admission of proper past-speech evidence, particularly as trial judges anticipate the risk of reversal under specialized double-jeopardy rules that permit postverdict appeals only by defendants, and not by government prosecutors.

Second, a rule of short-leash deference would take account of the practical challenges presented by requiring trial courts to engage in fact-specific balancing in past-speech-evidence cases. One difficulty baked into such a contextual balancing approach is that it inevitably will generate different assessments by different judges, including different assessments in the same case by trial courts and appellate tribunals. As a result, a regime of de novo review would inevitably produce full-blown retrials even in extremely close cases. Some analysts may see this outcome as salutary. In their view, the Constitution speaks with one voice to all courts, and the essential purpose of appellate review is to correct legal errors, especially in constitutional cases. On another view, however, the central goal of extending meaningful constitutional controls to past-speech-evidence

264. See, e.g., Rankin v. McPherson, 483 U.S. 378, 388 (1987); Pickering v. Bd. of Educ., 391 U.S. 563, 578 n.2 (1968).

265. Faulkner, supra note 5, at 21; Quint, supra note 2, at 1667; see also Anderson, supra note 5 , at 936,940 .

266. One can imagine a case, for example, in which the trial judge, because he is personally on the scene in pretrial proceedings, perceived a lessened risk of unfair prejudice in the use of the past-speech evidence than might otherwise exist because of the particular, case-specific unfolding of questions and answers in the jury-selection process. A rule of strict de novo review would preclude any consideration of such a factor; a rule of short leash deference, in contrast, would give such a factor some-but not determinative-significance. 
cases is more systemic in nature. Seen from this vantage point, the key aim of devising limits in this field is to ensure that trial judges work with care to protect the free-expression values that prosecutorial proffers of past-speech evidence tend to threaten. Perhaps a nodeference-at-all approach would work better than a short-leash deference rule to advance the cause of trial court attentiveness. But common sense suggests that such a minor difference in appellate techniques would not make much of a practical difference on this score. On the other hand, a short-leash-deference approach-by giving a modest benefit of the doubt to assessments made by trial judgeswould avoid the need for full-scale retrials in close-to-coin-flip cases, while taking account of whatever advantages trial judges have from being on the scene when the evidence is offered in real time for consideration by the jury.

Finally, a rule of short-leash deference, precisely because it is short leashed, is unlikely to undercut the key aim of developing meaningful limits on the admission of relevant past-speech evidence. After all, the use of probing, rather than deeply deferential, scrutiny will allow appellate courts to develop over time a coherent body of doctrine that marks the boundaries of permissible trial court action. No less important, this form of highly probing (even if not de novo) review will amply empower appellate tribunals to police the oversights and missteps of any single trial judge in the handling of particular proffers of past-speech evidence.

\section{The Test of Admissibility}

The final question concerning the judicial fashioning of pastspeech-evidence doctrine is the most central of all: When a court encounters a First Amendment challenge to the use of such evidence, what governing standard should it apply in ruling on its admissibility? Many answers to this question are possible. Courts could, for example, apply a rule of automatic exclusion once they decide that publicconcern speech is at issue. ${ }^{267}$ Such an approach, however, would run headlong into the Court's ruling in Haupt, as well as the Court's pronouncements in Dawson and Mitchell. ${ }^{268}$

267. See, e.g., Conspiracy and the First Amendment, supra note 123, at 894-95 (suggesting that protected past-speech evidence should automatically be excluded in conspiracy prosecutions).

268. Such an inflexible approach also would not fit together well with the contextual balancing framework set forth and defended in the public-concern-speech cases typified by Connick. See supra notes 232-42 and accompanying text. 
Another possibility would be to embrace a rule of near-automatic exclusion - for example, a rule that permits trial courts to admit pastspeech evidence only in "extraordinary circumstances." ${ }^{\text {269 }}$ Rules of this kind have a place in constitutional law. ${ }^{270}$ Indeed, the discourse of strict scrutiny-put to work in both Humanitarian Law Project and Sherbert-offers support for applying such an approach here. Adopting a rule of near-automatic exclusion, however, would raise a variety of problems. To begin with, neither the direct-in-effect-burden line of decisions typified by Humanitarian Law Project nor the compulsory-exemption rule of Sherbert fits perfectly together with past-speech-evidence cases. ${ }^{271}$ In addition, such an approach would raise tensions with both the Court's endorsement of the use of pastspeech evidence in Haupt and its rejection of a comparable expressionprotective standard for public-concern-speech cases in Connick. ${ }^{272}$ Most important, such a methodology would tip the balance heavily against the use of past-speech evidence-sometimes, highly relevant past-speech evidence-notwithstanding strong policies that support not only acquittal of the innocent but also conviction of the guilty. ${ }^{273}$

In sum, rules of automatic or near-automatic exclusion would unduly favor defendants and disfavor government prosecutors. As a result, courts might take exactly the opposite approach by holding that relevant past-speech evidence is never subject to First Amendment objections or that it is excludable in only "rare" or "extraordinary" instances. These approaches, however, would not take fair account of First Amendment freedoms rightly recognized by the Court as both "precious" and "vulnerable"274_ just as surely as rules of automatic or

269. Courts could define "extraordinary circumstances" to reference either the distinctly high probative value of the evidence, the distinctly high importance of ensuring conviction of the guilty, or both. Consider, for example, the hypothetical bombing case put forward in the Introduction. Consider also a recorded statement made the day before the bombing in which the defendant declared, "This government is so terrible I could blow up a building." Such a near-in-time, focused, and incontrovertible statement, even if addressing a matter of public concern, might well be admissible under such an "extraordinary circumstances" test.

270. See, e.g., City of Philadelphia v. New Jersey, 437 U.S. 617, 623-24 (1978) (recognizing a "virtually per se rule of invalidity" in facial-discrimination dormant Commerce Clause cases).

271. See supra notes 161-72 and accompanying text (discussing Holder v. Humanitarian Law Project, 561 U.S. 1 (2010)); supra notes 174-76 and accompanying text (discussing Sherbert v. Verner, 374 U.S. 398 (1963)) .

272. See supra notes 24-35 (discussing Haupt v. United States, 330 U.S. 631, 642 (1947)); supra notes 232-42 and accompanying text (discussing Connick v. Myers, 461 U.S. 138, 149 (1983)).

273. United States v. Nixon, 418 U.S. 683, 708-09 (1974) (emphasizing the "twofold" purpose of the criminal justice system, including that "guilt shall not escape" (citation omitted)).

274. NAACP v. Button, 371 U.S. 415, 433 (1963). 
near-automatic exclusion would not take fair account of countervailing societal interests. Among other things, these pro-prosecution standards would, as seen above, create discordance with modern precedents that pointedly call for "broad protection" of speech on matters of public concern. ${ }^{275}$ Indeed, a rare-cases-only approach would not only fail to provide such speech with "broad protection"; it would render First Amendment scrutiny in this context little more than an empty shell.

One might challenge this position by asserting that there is a special justification for endorsing a no-objections-ever or an extraordinary-cases-only prosecutor-friendly approach. The argument is that trial judges can deal with the problems presented by past-speech proof by delivering thoughtful limiting instructions, thereby reducing the danger of the jury's improper use of the problematic evidence. As discussed above, however, there are built-in difficulties with this approach due to the limited effectiveness of such instructions. ${ }^{276}$ In addition, there is a special problem with relying on cautionary instructions to deal with past-speech evidence because those instructions, by their very nature, cannot ameliorate burdens on expression that stem from either "fair prejudice" or chilling effects. The whole point of such instructions, after all, is to invite juries to consider past-speech evidence, while avoiding only the unfairly prejudicial use of such evidence in the process of deliberating in the particular case.

Given the difficulties raised by moving to either polar positionthat is, by embracing, on the one hand, an overwhelmingly progovernment or, on the other hand, an overwhelmingly pro-defendant approach to admissibility-some analysts have tried to steer a middle course. One synthesis would require judges to focus on the type of pastspeech evidence offered by the prosecution. Courts, for example, might declare that past speech that embodies art, such as rap music, enjoys categorical, or nearly categorical, protection from prosecutorial use as evidence. ${ }^{277}$ Because such an approach would give more favorable

275. See supra notes 73-91 and accompanying text.

276. See supra note 105 and accompanying text.

277. See, e.g., Michael Gregory, Murder Was the Case That They Gave Me: Defendant's Rap Lyrics As Evidence in a Criminal Trial, 25 B.U. PUB. INT. L.J. 329, 356 (2016) (arguing that rap lyrics should not be admissible unless the lyrics virtually "parallel the crime alleged"); Powell, supra note 122, at 523 (noting that one "solution would be to [exclude] defendants' rap lyrics ... unless they make some specific reference to a crime that only a guilty party would know about"); id. at 524-25 (advocating "a per se ban on rap lyrics in criminal proceedings" because of 
treatment to some speech than other speech based on content, however, it would be hard to square with the Court's often-expressed aversion to content-based categorizations in the regulation of protected expression. ${ }^{278}$

Perhaps in an effort to dodge this problem, Professor Quint floats the idea that speech-related evidence might be grouped into three categories, based not so much on the content of expression as on its form. According to this approach, past-speech evidence would be subject to a tripartite division, ranging from least protected to most protected, depending on whether it involves (1) activity in the form of actual statements by the defendant (for example, a profession like "I endorse Nazism."); (2) activity in the form of expressive association by the defendant (for example, membership in the Nazi Party); and (3) activity in the form of taking in others' expressive work (for example, attendance of a Nazi-sponsored rally or reading Mein Kampf). ${ }^{279}$ This way of thinking about past-speech evidence has some value, and courts should pay it heed as they engage in balancing in this set of cases. In the end, however, even Professor Quint does not advocate adoption of three distinct legal tests for each of these forms of speech-related activity. And wisely so. As Justice Kagan once observed, modern First Amendment law has spawned "technical, complex classificatory schemes" under which "categories have multiplied" and "distinctions grown increasingly fine." 280 To a large extent, this building out of freespeech doctrine reflects the inevitably rich complexities of life. With regard to past-speech evidence, however, there is little reason to conclude that endorsing a three-category analytical approach would be worth the candle. Even without creating rigid and confining analytical

\footnotetext{
"the potential chilling effect on the genre, accompanied by the fact that lyrics will not make or break the prosecution's case"); see also Anderson, supra note 5, at 902, 942-43 (proposing a more restrictive framework for the admission of evidence, under which " $[\mathrm{t}]$ he showing of relevancy should be more rigorous," for cases involving proof relating to the defendant's taste in music or other entertainment).

278. See Reed v. Town of Gilbert, 135 S. Ct. 2218, 2226 (2015) (noting that content-based laws are "presumptively unconstitutional").

279. Quint, supra note 2, at 1668-76. Some judges have moved, if haltingly, in this direction. See, e.g., Guam v. Shymanovitz, 157 F.3d 1154, 1158-59 (9th Cir. 1998), overruled by United States v. Curtin, 489 F.3d 935 (9th Cir. 2007) (en banc); Curtin, 489 F.3d at 963 (Kleinfeld, C.J., concurring) (distinguishing the case at hand from Haupt because Haupt involved "what a defendant said ... not what he merely read"); Anderson, supra note 5, at 937 (arguing for closer judicial scrutiny of speech "consumption" evidence because mere "[c]uriosity may drive us to try different materials").
}

280. Kagan, supra note 72 , at 515. 
categories, after all, courts can take account of these form-of-speech considerations.

Another middle-course approach for past-speech-evidence cases would constitutionalize the Rule 403 standard, which balances probative value against the risk of unfair prejudice in federal proceedings. In other words, this nonconstitutional rule set forth in the Federal Rules of Evidence would morph into a constitutional rule applicable in all federal and state prosecutions as a matter of entrenched First Amendment doctrine. ${ }^{281}$ One problem with this proposal is that Rule 403 was neither formulated to deal specifically with past-speech evidence nor constructed in an effort to restate Free Speech Clause limits. ${ }^{282}$ Even more important, this magical transformation of Rule 403 would put in place a First Amendment limit that is too lax. In particular, Rule 403 specifies that unfair prejudice must "substantially outweigh" probative value for exclusion to occur, and courts have emphasized this admission-friendly phrasing in overruling objections to speech-related proof. ${ }^{283}$ Thus, in the real world, few Rule 403 motions to exclude relevant evidence are granted. ${ }^{284}$ Indeed, the obstacles faced by defendants who assert Rule 403 objections are far-reaching, in part because the burden of justifying exclusion rests squarely on the objecting party, ${ }^{285}$ because that burden is a heavy one, ${ }^{286}$ and because discharging it requires an all-out focus

281. Cf. Herbert v. Lando, 441 U.S. 153, 177 (1979) (relying on the "firm[]" application of FED. R. CIV. P. 26(b) and 26(c) to protect First Amendment interests implicated by civil discovery of newsroom thought processes in defamation cases).

282. Prejudice-related questions, for example, could arise under Rule 403 if the prosecution's proof touched upon a defendant's past liaisons with prostitutes. Such evidence, however, has nothing to do with past speech, speech-related prejudice concerns, or speech-related chilling effects.

283. See, e.g., United States v. Moore, 732 F.2d 983, 989 (D.C. Cir. 1984) ("The language of this rule tilts ... toward the admission of evidence in close cases.").

284. As one commentator put the point, "Many Prayers Are Heard, Few Are Answered." Michael H. Graham, Relevance, Fed. R. Evid. 401, and the Exclusion of Relevant Evidence, Fed. R. Evid. 403: "Many Prayers Are Heard, Few Are Answered," 45 CrIM. L. Bull. 1080, 1080 (Nov.-Dec. 2009).

285. See, e.g., United States v. Cross, 308 F.3d 308, 323 (3d Cir. 2002) (holding that Rule 403 "creates a presumption of admissibility" (citation omitted)); Leah Tabbert, Note, Maximizing the Min-Max Test: A Proposal to Unify the Framework for Rule 403 Decisions, 100 MinN. L. REV. 2217, 2224 (2016) (same).

286. 1 CHRISTOPHER B. MUEller \& LAIRD C. KIRKPATRICK, FEDERAL EVIDENCE $§ 4: 12$ (4th ed. 2013) ("[T]he power to exclude evidence under Rule 403 should be sparingly exercised. The tenor of the language of Rule 403 supports this conclusion, since it contemplates admitting rather than excluding evidence when probative worth seems equally balanced against dangers like prejudice and confusion of the issues." (citation omitted)); David Crump, On the Uses of 
only on problems of unfair prejudice. ${ }^{287}$ For these reasons, the Rule 403 standard is likely to prove so feckless in practice that it would not functionally differ from an extraordinary-cases-only rule of inadmissibility. ${ }^{288}$ In sum, any properly operationalized First Amendment standard of exclusion needs to have a much stronger backbone than that of Rule 403.

Professor Quint attempts to work through these challenges by proposing a constitutional rule that would "reverse[] the ordinary test" of admissibility embodied in Rule 403. ${ }^{289}$ In other words, judges would have to exclude past-speech evidence "unless the government can establish that the probative value of the evidence substantially outweighs its prejudicial dangers. ${ }^{290}$ There is something to be said for Professor Quint's proposed methodology; at the least, it would afford past speech a meaningful measure of judicial protection. ${ }^{291}$ But this approach suffers from problems of its own. To begin with, the starting point for Professor Quint's reverse-403 presumption lies in the text of Rule 403, and there is - as noted earlier-no apparent reason why a constitutional limit should find its origins in this nonconstitutional rule of evidence law. Another difficulty with this reverse- 403 presumption is that it seems to rest on too circumscribed a view of "prejudice" because Rule 403 focuses on a factfinder's use of the evidence for impermissible purposes-to infer guilt, for example, because defendants are bad people, troublemakers, oddballs, or irritants. ${ }^{292}$ As

Irrelevant Evidence, 34 Hous. L. REv. 1, 3 (1997) ("Rule 403 .. is biased in favor of admissibility."); Eileen A. Scallen, Analyzing "The Politics of [Evidence] Rulemaking", 53 HASTINGS L.J. 843, 880 (2002) ("The word 'substantially' tilts the balance of Rule 403 toward admissibility.").

287. See infra notes 292-96.

288. See, e.g., Faulkner, supra note 5, at 6 (deeming Rule 403 review "constitutionally insufficient," in part, because "it weights the balancing process towards ... admission"); id. at 24 (adding that even reforming Rule 403's test to equalize the roles of probative value and prejudicial effect would "not provide sufficient protection to First Amendment rights").

289. Quint, supra note 2, at 1662.

290. Id. (emphasis omitted).

291. See 22 Charles Alan Wright \& Kenneth W. Graham, Jr., Federal Practice AND PROCEDURE $§ 5195$, at 313 (2009 Supp.) (characterizing as "persuasively argued" Quint's position that "the First Amendment imposes restrictions on the use of political speech and associations in criminal prosecutions").

292. See FED. R. EVID. 403 advisory committee note (indicating that "prejudice" is "[u]nfair" if it has "an undue tendency to suggest decision on an improper basis"); Old Chief v. United States, 519 U.S. 172, 180 (1997) (defining "unfair prejudice" as concerning dangers that the factfinder might be "lure[d] ... into declaring guilt on a ground different from proof specific to the offense charged"). But see Imwinkelried, supra note 123, at 888-93 (suggesting that judges may consider extrinsic social policies in making Rule 403 admissibility determinations). 
previously demonstrated, however, the use of past-speech evidence burdens First Amendment rights for reasons that reach well beyond this single form of prejudicial effect. ${ }^{293}$ The underlying problem is that the reverse-403-presumption test sharply differentiates between "fair" and "unfair" uses of evidence in that Rule 403, by its terms, focuses only on the risk of "unfair prejudice." 294 Even "fair" prejudice, however, gives rise to a burden that should weigh in the balance when speech on matters of public concern is at issue. ${ }^{295}$ So, too, should systemic concerns about chilling effects. ${ }^{296}$

Ultimately, composing the precise wording of a legal formula for gauging the admissibility of relevant past-speech evidence is less important than embracing the basic principle that the First Amendment requires courts to evaluate the evidentiary use of such speech in a meaningful way. In the picture, too, is the fact that the interests of the government and of the defendant will inevitably clash in these cases in a wide-ranging and unpredictable variety of ways. With these points in mind, perhaps the best course is to avoid stating any operative limit in the technical jargon of the law - such as by laying down a formula that speaks about a "presumption"297 or (worse yet) the "reverse" of a preexisting presumption ${ }^{298}$ or that otherwise makes use of the lawyerly phraseology of Rule 403. Courts also would do well to eschew metaphorical flourishes that allude, for example, to "placing a thumb on the prejudice and confusion side of the scale." 299 Instead, the best approach-because it is the most comprehensive and directwould articulate the controlling proposition in unadorned terminology. Such a formulation might read something like this:

When an objection is made to proffered evidence that involves speech on a matter of public concern, the court must balance with care the relevance of the evidence against the threatened burden on First Amendment rights. In doing so, the court must take full account of the constitutional centrality of those rights and recognize that the

293. See supra Part II.B-C.

294. See, e.g., United States v. Hammoud, 381 F.3d 316, 341 (4th Cir. 2004) (emphasizing this point), vacated by Hammoud v. United States, 543 U.S. 1097 (2005).

295. See supra notes 111-13 and accompanying text.

296. See supra Part II.C.

297. Faulkner, supra note 5, at 6, 21 (deeming past-speech evidence "presumptively prejudicial"); accord Donohue, supra note 110, at 233.

298. See supra note 289 and accompanying text.

299. United States v. Ring, 706 F.3d 460, 473 (D.C. Cir. 2013). 
threatened burden on them reaches beyond the risk of unfair prejudice to the objecting party in the factfinding process. ${ }^{300}$

Other formulations along these lines can be, and no doubt will be, framed by judges and commentators. ${ }^{301}$ It bears emphasis, however, that the development of the law in this area will depend most of all on the contextual adjudication of concrete disputes on a case-by-case basis, regardless of any legal "test" that courts lay down to guide the balancing process. As courts navigate this process, they must attend not only to the immediate pressures to admit relevant evidence, but also to the enduring and systemic concerns underlying the First Amendment.

\section{Applications}

Limitations of time and space preclude a detailed treatment in this Article of how these principles might operate in practice. As it turns out, however, much good work along these lines already exists. Professor Andrea L. Dennis, for example, has thoughtfully grappled with the special problems presented by rap-music evidence. ${ }^{302}$ Robert P. Faulkner has focused, in a similar fashion, on the intersection of Noerr-Pennington principles and evidence law. ${ }^{303}$ Professor Quint's pathbreaking article has directed attention to past-speech evidence in the form of high-octane political dissent. ${ }^{304}$ Courts should take care to consider these helpful treatments as they work their way through pastspeech-evidence cases.

Courts also should pay attention to accepted paradigms and wellreasoned precedents. In United States v. Ring ${ }^{305}$ for example, the Government offered-and the court admitted-evidence of the

300. For a similar suggestion, see Nickerson, supra note 6, at 877 (requiring "a showing more demanding than mere relevance" to gain court-ordered disclosure of speech-related evidence); see also Lawrence Rosenthal, First Amendment Investigations and the Inescapable Pragmatism of the Common Law of Free Speech, 86 IND. L.J. 1, 8-9 (2011) (advocating a case-specific "pragmatic balancing" approach for assessing the constitutionality of government reliance on protected speech activities to initiate criminal investigations; and collecting supportive authority for this position).

301. See, e.g., Dennis, supra note 4, at 30-31 (embracing a "balanced approach" under which courts would focus on the "unfairly prejudicial nature" of rap lyrics); id. at 33 (adding that "[j]udges should approach the admissibility determination from" the "vantage point ... of the lyricist").

302. See generally id. (discussing this issue at length).

303. See Faulkner, supra note 5, at 29-35.

304. See generally Quint, supra note 2 (examining the introduction of evidence of membership in the Communist Party by the Government in the Rosenberg trial).

305. United States v. Ring, 706 F.3d 460 (D.C. Cir. 2013). 
defendant's past-speech activity in the form of campaign contributions. ${ }^{306}$ This evidence was offered to show that he used such contributions not as bribes, but as a stepping stone to secure access to officeholders whom he later would try to bribe. ${ }^{307}$ This ruling is defensible, but only because the evidence concerned contributions made to candidates of a mainstream party. If the proof showed, for example, that the defendant had channeled funds to Nazi Party candidates, so as to gain access to their officeholder friends, a very different case would be presented, even though the relevance of the past-expression evidence in each case might seem to be the same. In terms of the risk of prejudice, after all, it is one thing to support the campaigns of Republicans and Democrats. It is quite another thing to send money to Nazis.

Courts also should take care to consider dividing up proffered past-speech evidence into separate component parts. It might well be, for example, that a trial judge can and should admit evidence of a defendant's gang membership, together with proof of the gang's commitment to cross-gang killings, to establish the motive for an alleged murder. ${ }^{308}$ But the same judge might simultaneously exclude proffered evidence of the defendant's writing of gang-related rap lyrics that both embody artistic social commentary and tend to show the defendant's motive only in a tenuous way. Past-speech evidence is oftentimes divisible in this way. Trial judges should be attentive to that fact, looking for chances to break apart clusters of past-speech evidence, admitting portions of it that are highly relevant, but excluding portions that have only marginally probative value.

Revisiting the first paragraph of this Article brings into focus a recurring problem raised by past-speech evidence-that is, the problem of how to evaluate such evidence when it is offered to prove a defendant's state of mind. At the trial of Julius Rosenberg, for example, prosecutors presented evidence that the defendant had expressed a preference for the Communist system of government. Their purpose in offering this evidence was to help prove that the defendant had in fact passed secret information to the Soviets by

306. Id. at $472-74$.

307. Id.

308. Notably, the court might reason either that membership in a murderous gang is not a matter of public concern or, alternatively, that the relevance of such evidence outweighs the risk of prejudice it poses. 
showing the jury that he had a motive for doing so. ${ }^{309}$ Proof of a preference for one form of government over another, however, links up only in the loosest way with committing acts of espionage, ${ }^{310}$ and the acute risk of unfair prejudice in such a case-which occurred at the height of the Red Scare - is not hard to see..$^{311}$

In telling contrast, the Court in Haupt dealt with past-speech evidence offered for a very different purpose. There, the prosecution did not tender the defendant's prior statements merely to prove an underlying motive, so as to suggest circumstantially that the defendant engaged in the actus reus of the offense. Instead, the prosecution offered the proof to establish (probably in the only way possible) a mens rea element fixed by the statutory prohibition itself-namely, that the defendant acted with a specific intent to aid the enemy. ${ }^{312}$ Put another way, Julius Rosenberg's past speech was used to prove through inference that certain conduct had occurred, while Haupt's past speech was used to prove directly his state of mind, a statutory element. In addition, the evidence in Haupt involved much more than an expressed preference for one form of government over another; indeed, the father's declaration that he would kill his son if he fought against Germany signaled an intense and focused enmity that reached far beyond simply endorsing an unpopular point of view. ${ }^{313}$ For these reasons, the Court's ruling in Haupt is reconcilable with the mode of analysis put forward in this Article. On the other hand, there is good reason to conclude that the Second Circuit's ruling in Rosenberg did not take fair account of the free-speech values at stake in the case. ${ }^{314}$

309. Quint, supra note 2, at 1634-36.

310. Id. at 1669 .

311. Id. at 1639 (noting the "grave dangers of prejudice" that arose because the Rosenbergs' trial came "in the heart of the Cold War period").

312. See generally supra notes 24-29. The charged crime of treason included a specific-intent element with regard to aiding the enemy. See supra note 27. Particularly in a treason case such as Haupt-where another plausible motive (here, parental love) is clearly in the picture - it typically will be very difficult to prove the defendant's entirely inner mental state without any resort to past expressions of the defendant's thinking.

313. See supra note 29. Most of us, for example, want very much for skilled players on our sports teams not to shift allegiances to a despised rival. But few of us would find reason to declare that we would kill those players in the event that they choose to do so.

314. One set of cases that highlights the distinction between background-motive and intentelement inquiries involves antidiscrimination laws. In these cases, plaintiffs and prosecutors seek to use past-speech evidence to prove a prohibited discriminatory mental state as part of a criminal or civil proceeding. The laws that give rise to such cases require proof of some adverse actionfor example, a failure to hire, a firing, a battery, or a killing - taken by the defendant with the specific intent to act because of the victim's race, gender, or other legally specified personal 
Even precedents that do not involve evidentiary issues might prove useful to courts as they undertake context-sensitive balancing in past-speech-evidence cases. In Connick, for example, the Court rightly emphasized that judges should distinguish between speech that lies at the heart of the First Amendment and speech that travels near the outer edges of the public-concern concept. ${ }^{315}$ Other considerationssuch as the recency of the speech, ${ }^{316}$ its isolated character ${ }^{317}$ its distinctive potential for creating prejudicial effects, ${ }^{318}$ its packaging in forms that are "frequently exaggerated or polemical," 319 and its immediate or more attenuated relevance to contested factual

characteristic. See generally United States v. Cannon, 750 F.3d 492, 508 (5th Cir. 2014) (collecting illustrative attempted uses of past-speech evidence in antidiscrimination cases). Many of these cases involve the evidentiary use of racist or sexist speech that has occurred during the actual course of a discrete prohibited action - as when, for example, a defendant screams racial slurs while engaging in a violent assault. Not surprisingly, such evidence is routinely admitted because it involves, in the most focused way, the defendant's own indication of the requisite wrongful intent as to the very act in question. In other cases, forms of past-speech proof that are less directly connected to the act in question - such as the defendant's past expression of racist views - may be allowed into evidence if they, too, are relevant to show a wrongful animus that is an element of the legal prohibition. See Price Waterhouse v. Hopkins, 490 U.S. 228, 251 (1989) (observing that "stereotyped remarks can certainly be evidence that gender played a part" in an employment decision challenged under an antidiscrimination law). In essence, that is what happened in Haupt, although the statute at issue in that case was not an antidiscrimination law. As Professor Quint explains, use of past-speech evidence to prove a statutorily required wrongful intent is typically far less problematic than the use of such speech, as in the Rosenberg case, to show an underlying motive for the purpose of proving that the defendant engaged in actions he denies having taken. Why? Because "fewer inferential steps are necessary" to prove an illicit "intent" directly from the defendant's speech. On the other hand, indirectly proving the defendant's commission of an act by using speech to establish an underlying motive involves nothing more than an effort to offer only one piece of (often highly tenuous) circumstantial evidence to establish the actus reus of the offense. Quint, supra note 2, at 1670-71. Moreover, as suggested in the discussion of Haupt in the text, "speech is often the only ... evidence bearing on the question of intent." $I d$. To say the least, the same is not true with respect to the question whether the defendant committed the actus reus of the crime charged. Id.; see also Anderson, supra note 5, at 935-36 (sharply distinguishing between cases in which the statute establishes as an element a particular form of wrongful intent and cases in which the prosecutor seeks only to prove a motive, which is not an element of the crime charged, so as to support the inference that the defendant engaged in a particular action in which the defendant denies having been involved).

315. See Connick v. Myers, 461 U.S. 138, 152 (1983) (suggesting greater likelihood of success in asserting a First Amendment claim "if the employee's speech more substantially involved matters of public concern").

316. See Dennis, supra note 4, at 33.

317. See id.

318. See id.

319. Quint, supra note 2, at 1669; see also Dennis, supra note 4, at 25 (questioning the recurring admission of rap-music evidence because rappers "are akin to fiction writers"). 
issues ${ }^{320}$-also should weigh in the decisional balance. ${ }^{321}$ The key point is that courts must approach the balancing process with thoughtfulness - thoughtfulness that should increase if, as suggested earlier, they must craft case-specific justifications for their rulings only after considering evidentiary objections in focused hearings conducted outside the presence of the jury.

\section{CONCLUSION}

As noted by a leading authority on the subject, "Writers have sometimes urged courts to use ... the First Amendment to limit the use of evidence. Judges do not seem enthusiastic about doing this." ${ }^{222}$ This assertion is both true and troubling. In declining to scrutinize pastspeech evidence with care, lower courts have both overread key Supreme Court precedents and undervalued the free-speech interests these cases present. Of particular importance, those courts have paid too little attention to modern developments in the First Amendment field, particularly case law that aggressively protects speech on matters of public concern and requires courts to evaluate thoughtfully asapplied challenges to speech-impairing generally applicable laws. This Article points the way to an improved approach. The establishment of meaningful, but nonburdensome, procedural requirements would foster decision-making care as judges assess past-speech evidentiary objections. And a vitalized substantive rule of exclusion-one that reaches well beyond Rule 403 by taking meaningful account of all the burdens imposed on free-speech values by the use of such evidencewould help ensure that courts, in this set of cases, afford our most fundamental liberties their fair due.

320. Dennis, supra note 4, at 33 (focusing on the close connectivity of prior-speech evidence to, for example, a particular crime-connected modus operandi); Quint, supra note 2, at 1670-71 (distinguishing "general political views from views of greater specificity bearing on the alleged offense[s]"); see also id. at $1671 \mathrm{n} .169$ (discussing, in this vein, specificity-laden past speech, such as an address calling on listeners to block traffic on a bridge, offered to show the speaker's intentional engagement in that behavior); id. at 1674 (noting that inferring intent from membership in a political group is a logically weak connection).

321. Quint, supra note 2, at 1676. Another relevant factor might be the extent to which the defendant has "opened the door" to an investigation of such matters as his political beliefs through the offering of his own evidence or arguments in the case.

322. 22A Charles Allen Wright \& Michael H. Graham, Jr., Federal Practice AND PROCEDURE $\$ 5195$ (4th ed. 2014) (citations omitted). 